\title{
Architettura archeologia per il rilievo integrato, il caso esemplare di Cuma: le Terme del Foro
}

\author{
Riccardo Florio \\ Raffaele Catuogno \\ Teresa Della Corte \\ Veronica Marino \\ Antonia Valeria Dilauro
}

\section{Abstract}

Il presente contributo vuole illustrare le fasi esplorative ed operative di acquisizione dei dati relative ad un sito archeologico di notevole importanza, il Parco Archeologico di Cuma, con un approfondimento sulle Terme del Foro. Si descriveranno le diverse fasi di studio che attraverso una mappatura ragionata delle preesistenze stanno consentendo al gruppo di lavoro di effettuare una rigorosa ricognizione ed acquisizione dell'intera città entro le mura, acropoli e città bassa, che ne consentirà la documentazione ed il trasferimento dei dati in rete per consentirne la fruizione ampia e controllata, anche dal punto di vista scientifico.

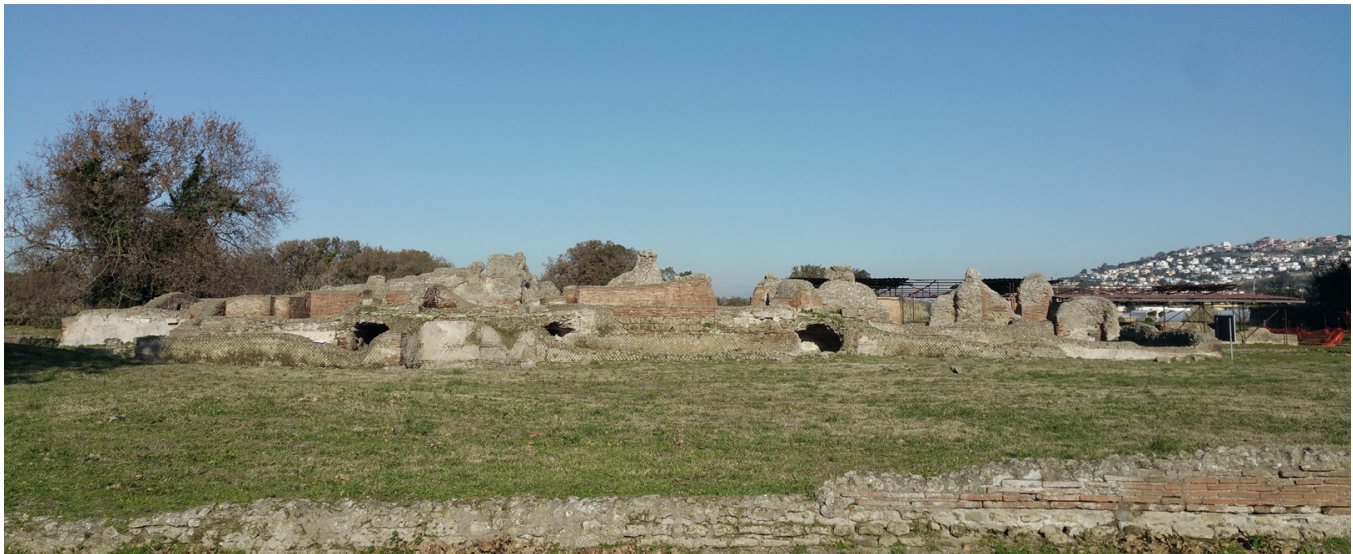




\section{Metodologie di rilievo integrato per la conoscenza del sito archeologico di Cuma}

Il lavoro di ricerca che qui presentiamo concerne lo studio e la lettura comparata, mediante un'attenta operazione di rilievo integrato, delle architetture e delle vestigia archeologiche situate all'interno del Parco Archeologico di Cuma, esteso su un'ampia superficie del limite settentrionale dei Campi Flegrei.

I luoghi in origine si presentavano completamente diversi dall'attuale assetto, soprattutto per le significative variazioni della linea di costa rispetto a quella antica, tale che la collina sulla quale si sarebbe insediato il sito di Cuma era in origine lambita su tre lati dal mare ed accessibile solo da sud, mentre a nord il territorio acquitrinoso la muniva di ulteriori difese naturali.

La polis di Cuma venne fondata dai Greci, provenienti dalla vicina Pithekoussai (Ischia), nel 730 a. C., istituendo sulla collina l'Acropoli e i santuari, ed alla base di essa in un'area piana ed ampia venne costruito l'abitato. La 'città bassa', cosiddetta, era delimitata da un quadrilatero irregolare di mura urbane e si estendeva per una superficie di circa I I 0 ha. Dalle evidenze emerse da recenti studi l'impianto della città non era di tipo ippodameo, ma si individuano alcuni assi più o meno paralleli alla costa che assecondavano la struttura morfologica del suolo e suddividevano la città in settori; questi si intersecavano con altri assi ortogonali di minore ampiezza. In essa le sporadiche esplorazioni condotte nel '700 e nel '900 hanno rilevato testimonianze di edifici del periodo sannitico e romano, soprattutto nella zona del Foro con il suo portico in tufo: il Capitolium, il Tempio con portici sul lato meridionale della piazza, la masseria del Gigante, le Terme Centrali e le Terme del Foro.

Fig. I. Planimetria dell'area

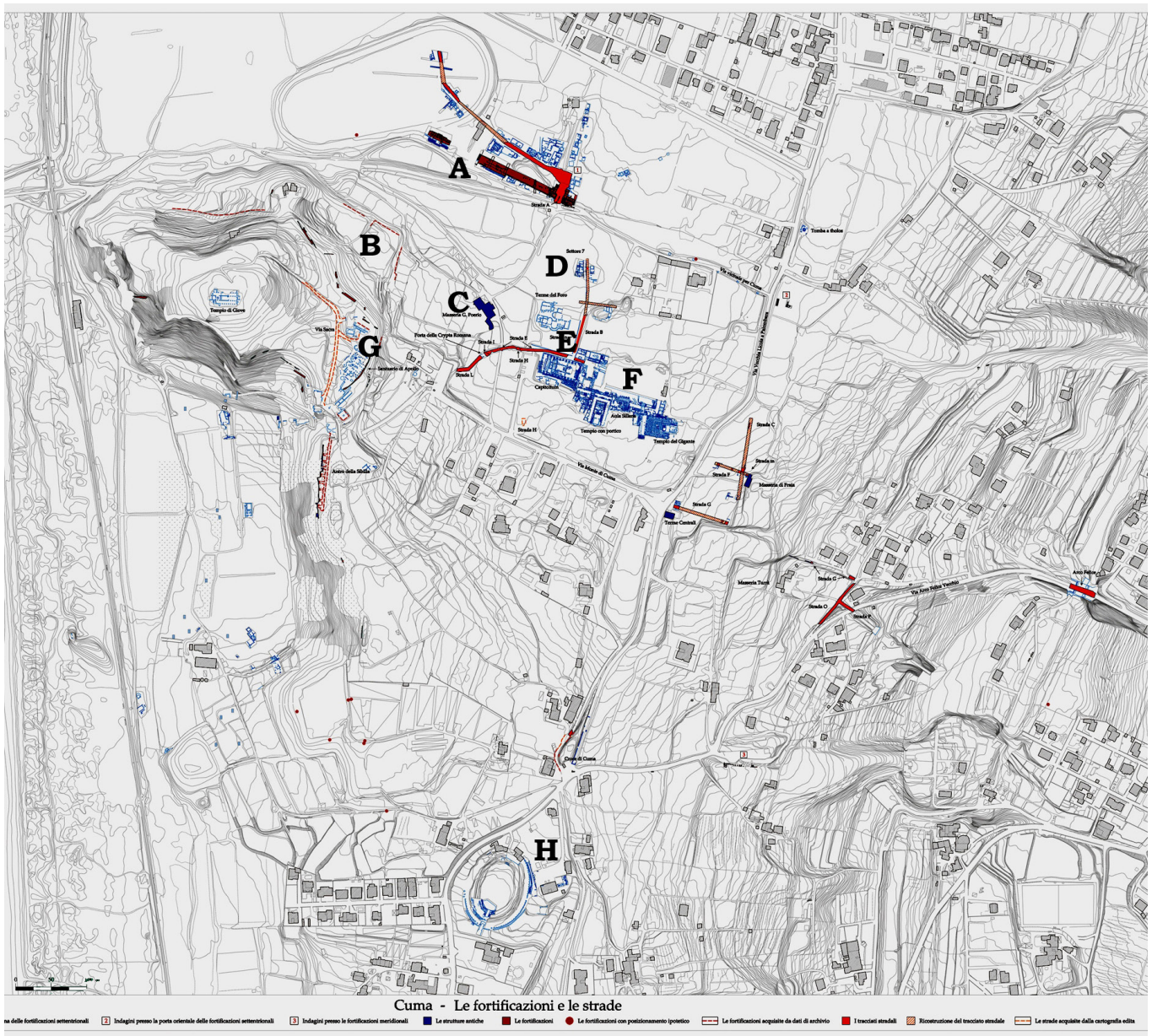


Lo studio si è concentrato, in questa fase, sulla 'città bassa' con l'obiettivo precipuo di sviluppare due diverse fasi di indagine: una ad ampio spettro che possa restituire la totalità delle consistenze e sia in grado di definire, con misurazioni scientifiche, i perimetri degli scavi attuali e dare indicazioni utili per le operazioni future; l'altra, assolutamente correlata alla prima, di lettura approfondita di uno complessi più rilevanti: le Terme del Foro.

Le operazioni di rilievo integrato hanno mirato alla creazione di un frame work riutilizzabile ed implementabile in base alla sperimentazione delle varie possibilità, legate, ad esempio, a dimensione, tipologia e/o difficoltà di acquisizione dei dati. Sono state utilizzate tecniche no-contact basate sia su tecnologia image-based che su tecnologia laser-based, sfruttando la fotografia e il laser scanning in maniera integrata. In particolare, il sistema TLS (Terrestrial Laser Scanner) è stato adottato per l'acquisizione ad alta risoluzione delle consistenze morfometriche delle architetture e dei reperti, mentre il sistema SAPR (Sistema Aeromobile a Pilotaggio Remoto) è stato utilizzato per acquisire immagini e video che documentano i beni culturali nel loro insieme; attraverso operazioni di volo programmato sono state acquisite immagini per la modellazione fotogrammetrica, consentendo la costruzione di un modello digitale misurabile del sito archeologico.

Le operazioni condotte secondo una metodologia integrata che, awalendosi sinergicamente della accuratezza delle strumentazioni innovative e della peculiare attitudine comparativa dei metodi di layerizzazione e rappresentazione 3D e di fotomodellazione digitale, vuole innestarsi proficuamente nel processo conoscitivo di tipo tradizionale.

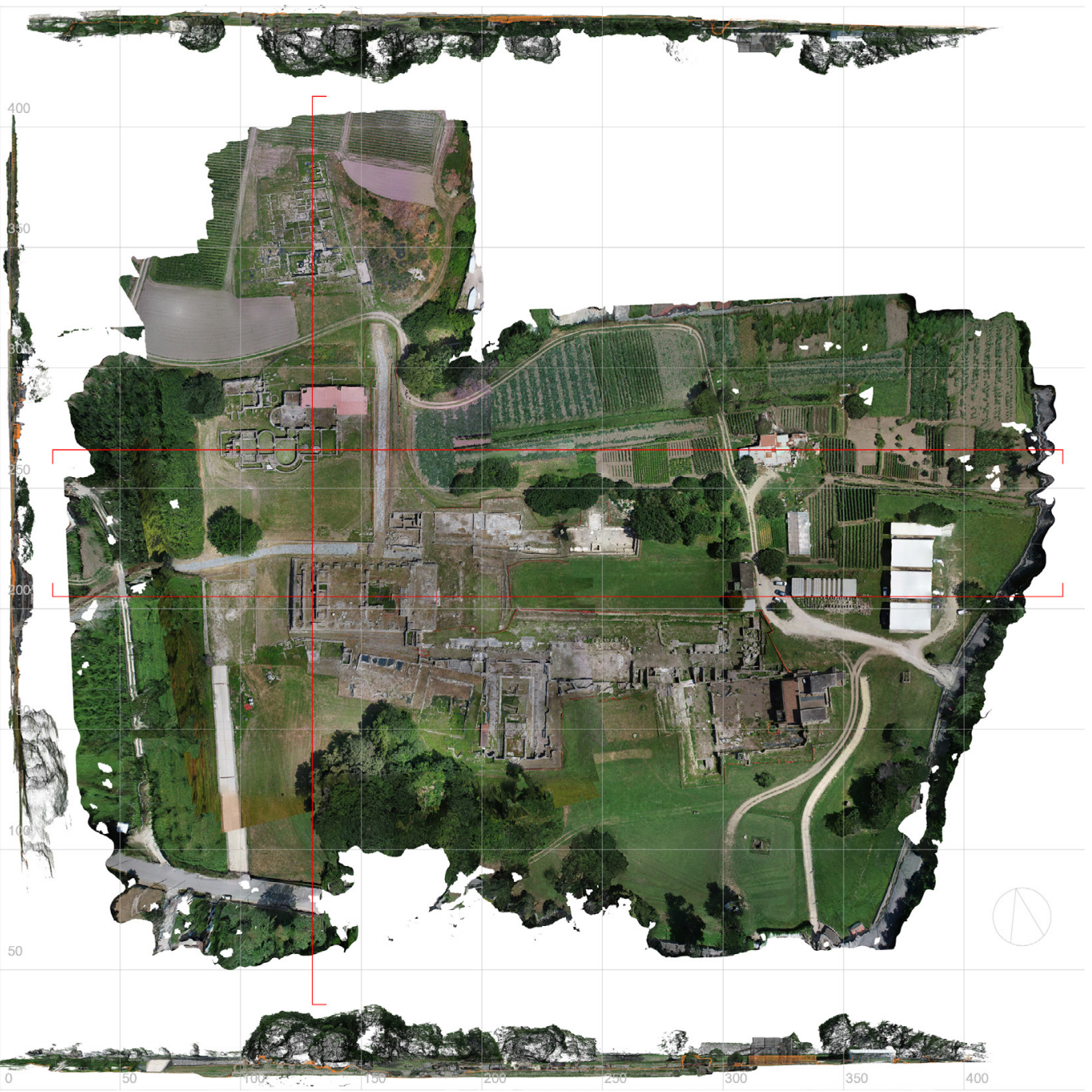


Sulla scorta dei numerosissimi dati restituiti si è voluto istituire un processo di ri-decodificazione che sposta la lettura dalle trasposizioni figurative della manualistica settecentesca e ottocentesca, nella sua esigenza conoscitiva, tassonomica e ricostruttiva, alla forma rappresentativa del presente.

La restituzione analitico-matematica dei processi numerici, fondanti il ricorso circolare dell'assunzione delle informazioni, ha sì consentito di ritrovare le caratteristiche materiche e architettoniche delle antiche vestigia e le loro radici geometriche, ma ha anche provocato una rivelazione che ne ha conclamato le specifiche peculiarità urbanistiche e architettoniche. (R.F.).

\section{Analisi storico-architettonica e individuazione delle fasi costruttive}

Lo studio dell'antico impianto delle Terme del Foro è stato indirizzato ad approfondirne l'analisi storico-architettonica attraverso la sinergica integrazione tra le più avanzate tecnologie di rilevamento. Inserendosi nel processo conoscitivo dinamico proprio dei siti archeologici complessi che necessitano di progressivi aggiornamenti interpretativi, le operazioni condotte hanno permesso di individuare, e registrare nella rappresentazione, le peculiarità del complesso, affiancando agli studi archeologici e alle documentazioni pregresse accurate documentazioni grafiche e infografiche, per proiettare il necessario impegno interdisciplinare verso una corretta politica di tutela e valorizzazione del sito.

L'immediata e puntuale intellegibilità delle consistenze architettonico-archeologiche superstiti ha supportato il fondamentale, e necessario, ruolo ermeneutico insito nella ricostruzione delle fasi di vita del complesso: si sono evidenziati non solo i rapporti tra gli ambienti originari condensati nei resti, ma anche, efficacemente, le variazioni e le anomalie presenti tra le diverse tessiture murarie, valorizzando le tracce più latenti, quali quelle materiche e cromatiche, in grado di rivelare e quindi rendere scientificamente validabili gli assetti stratificati relativi alle varie epoche.

Sorto su un preesistente insediamento residenziale, l'originario impianto termale viene correntemente fatto risalire alla fine del I sec., con buona probabilità all'età adrianea, in riferimento a una intensa fase di attività edilizia che seguì alla realizzazione nel 95 della via Domitiana. Fattori maggiormente determinanti per l'attendibilità di tale datazione sono tuttavia ascrivibili all'impiego di opere murarie e di materiali propri di detta epoca nel contesto territoriale flegreo, ma soprattutto la corrispondenza tipologica della pianta del complesso con l'half-axial ring type, molto diffuso nell'Italia romana del periodo.

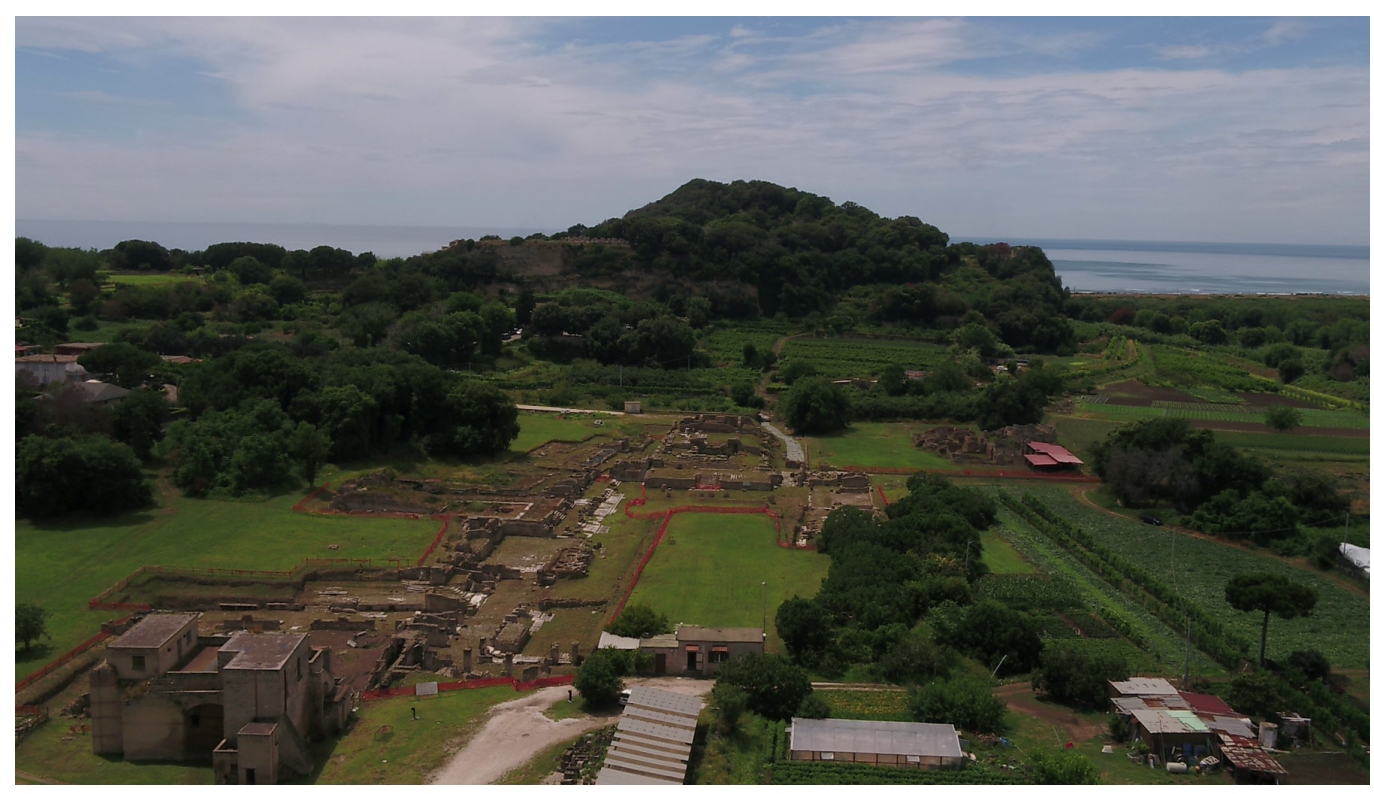


L'articolazione degli ambienti in situ si configura in modo semi simmetrico, privilegiando l'assialità scenografica dominata da due grandi colonne in marmo di Caristo e protesa tra il vestibolo d'ingresso e la vasca semicircolare del frigidarium, organizzando su un parallelo asse secondario la concatenazione mistilinea degli spazi caldi che culmina nel calidarium. La sequenza di essi riscontra nei resti la peculiarità del progressivo aumento della temperatura verso i prefurnia. L'esame delle partiture murarie ha rilevato come originaria la sala rettangolare a nord-est del vestibolo e l'ambiente anteposto al percorso termale e vicino alla palestra, adibito ai massaggi. Unico ambiente temporalmente non contestuale è la sala quadrata di fianco all'ingresso, aggiunta in epoca successiva come manifesta l'impiego di materiali diversi e il distacco delle murature contigue a quelle d'origine. L'integrazione dei dati ha consentito di formulare l'ipotesi di un lungo periodo di vita e funzionalità testimoniato da numerosi interventi di conservazione e consolidamento delle strutture. Altre tracce, modificando la fruibilità di alcuni spazi, danno consistenza all'ipotesi di una successiva funzione del complesso, non permanente ed anticipatoria dell'abbandono alla fine $V$ sec.; un riuso più duraturo sembra aver interessato le strutture delle cisterne. (T.D.C.).

Fig. 4. Schematizzazione delle caratteristiche dell'impianto originario delle fasi oninario del sito delle terme For sito delle terme del Foro [Guardascione 2019], indicazione della sequenza degli spazi cald freddi, di disimpegno e d servizio.
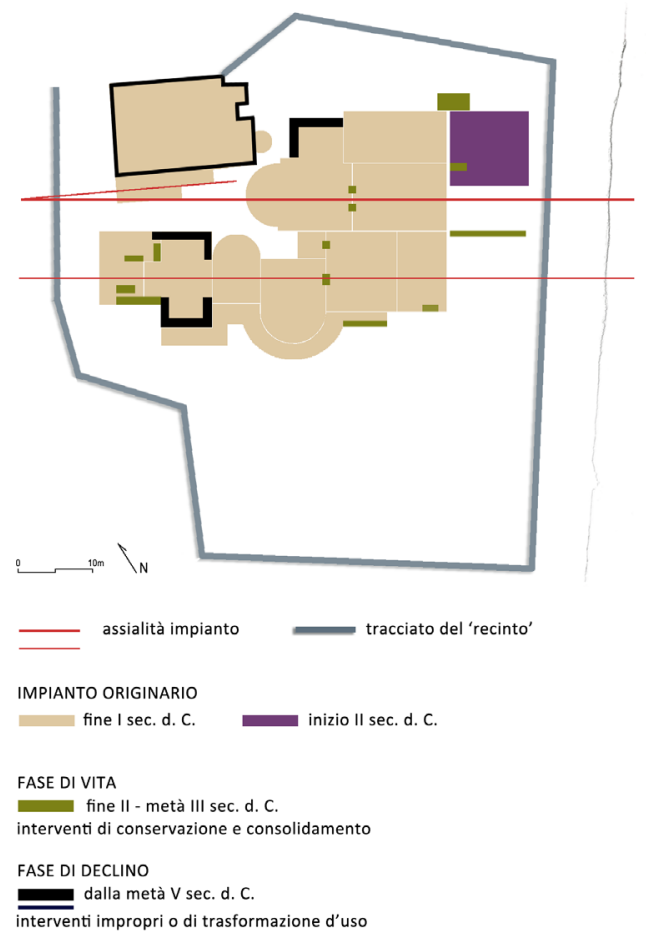

interventi impropri o di trasformazione d'uso

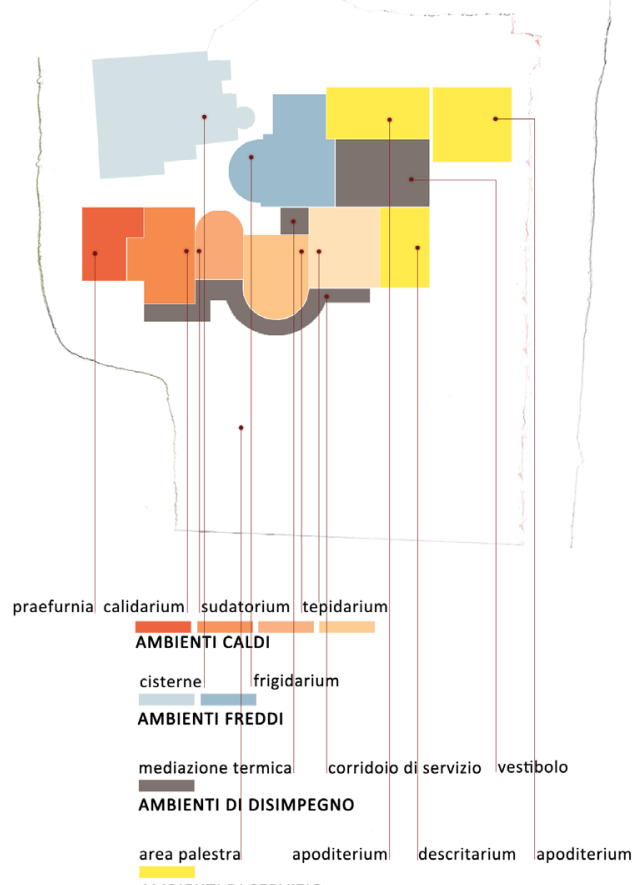

AMBIENTI DI SERVIZIO

\section{Il metodo image-based modeling per il rilievo integrato}

Per il Parco Archeologico di Cuma, in particolare per la città bassa, sono state effettuate due campagne di rilievo, giugno 2018 e giugno 2019, restituendo due aree a ridosso delle Terme del Foro, opportunamente georiferite attraverso GCP (Ground Control Point) distribuiti lungo il perimetro e all'interno dell'area rilevata e materializzati attraverso target RAD, per una superficie di $100.000 \mathrm{mq}$. II lavoro di acquisizione delle immagini, di elaborazione e restituzione dei dati è durato due mesi. Per la scelta della metodologia, dopo avere effettuato due sopralluoghi preliminari per pianificare le operazioni da compiere, si è deciso che quella più adatta fosse la modellazione fotogrammetrica per un inquadramento dell'area con la restituzione di un primo modello mentre per il rilievo delle emergenze archeologiche si è optato per un rilievo strumentale con laser scanner. 


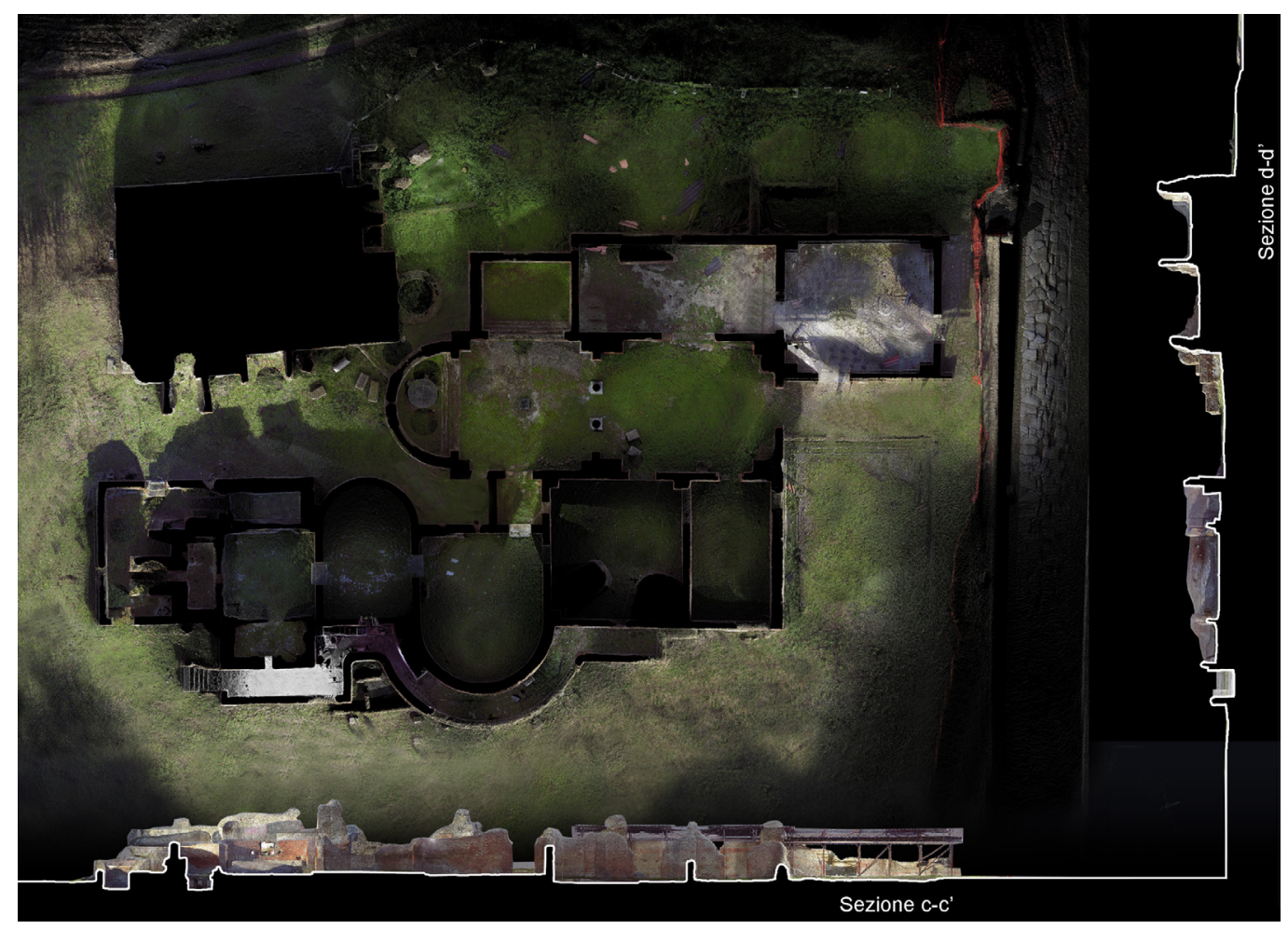

Figg. 5, 6. Terme del Foro. Ortoproiezione e sezio da nuvola di punti TLS

(Terrestrial Laser

Scanner).

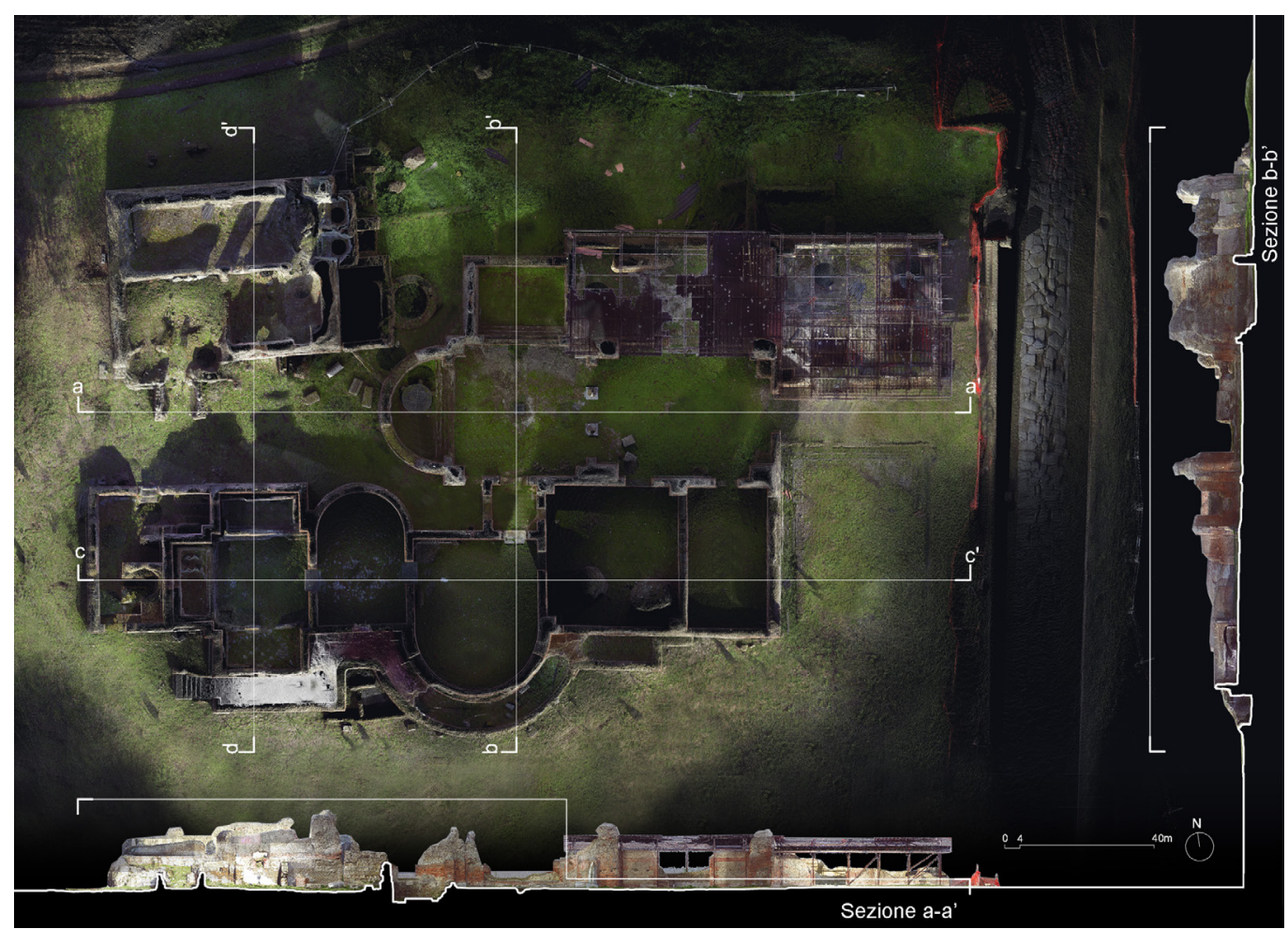


Fig. 7. Analisi architettonica degli spazi caldi praefurnia, calidarium, sudatorium e tepidarium condotta elaborando e interpretando dati rilevati con tecnologia laser scanner. Le configurazioni complessive di hypocaustum e concameratio sono dedotte dai resti cossibili
Saranno effettuati altri voli di uguale estensione per poter acquisire l'intera area con 6 missioni, utilizzando punti topografici per unire i diversi rilievi, mentre si procederà, come per le Terme del Foro, ad approfondimenti con rilievo strumentale con laser scanner.

Tale tecnica, infatti, ha consentito l'acquisizione di dati morfo-metrici del sito archeologico in oggetto restituendo la consistenza delle emergenze presenti nell'area.

II processo è stato finalizzato alla creazione di un modello tridimensionali per la ricostruzione dello stato di fatto come strumento d'indagine per la creazione di ortofotopiani del sito.

Si è proceduto quindi all'acquisizione attraverso SAPR (Sistema Aeromobile a Pilotaggio Remoto) di immagini aeree sia nadirali che a differenti angolazioni da utilizzare nei software di modellazione fotogrammetrica.

È stato necessario un progetto preliminare di presa basato su una mappatura dell'area con Mission Planner, un software per la realizzazione del piano di volo attraverso l'impostazione

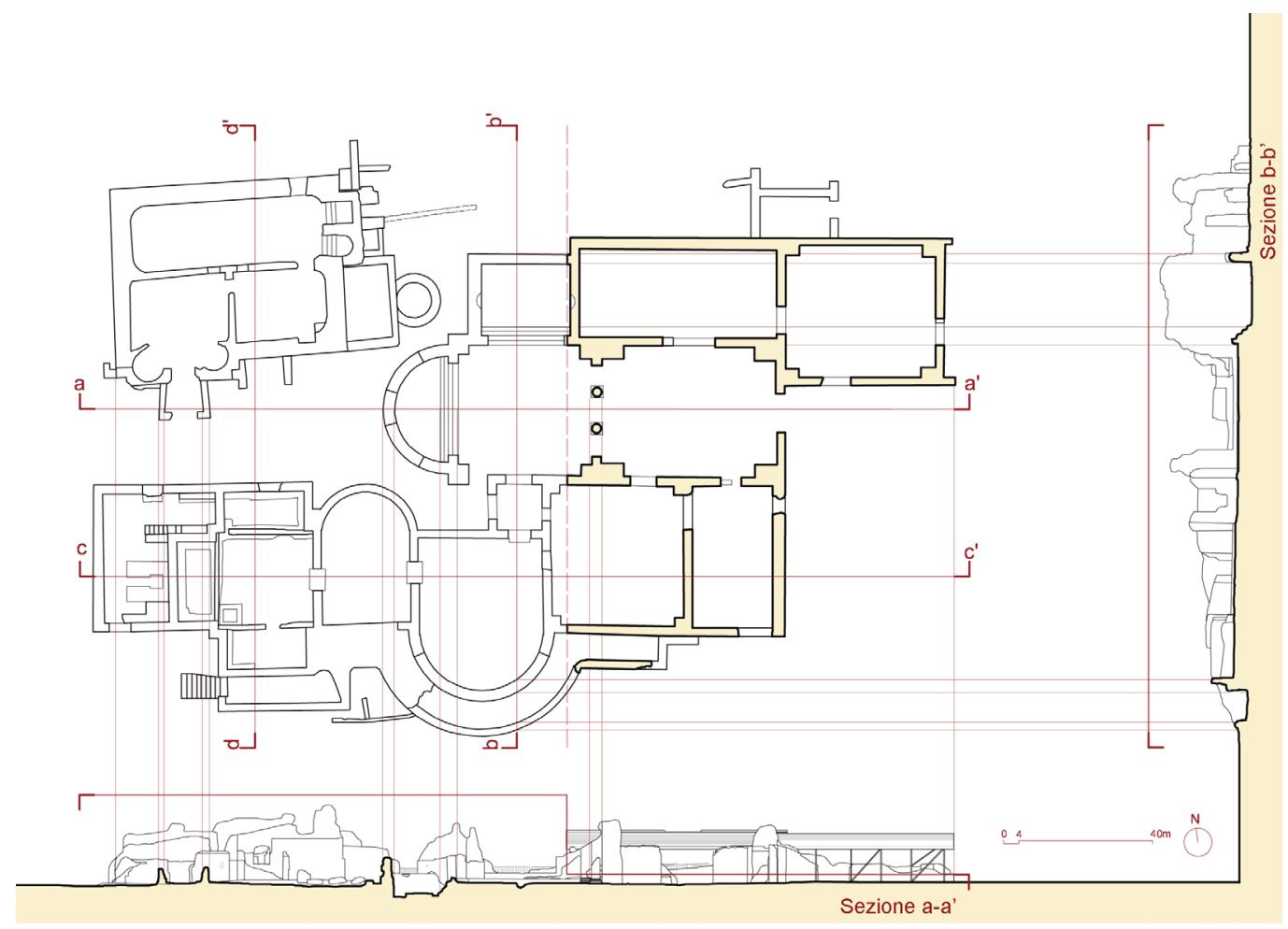

di quota del velivolo, lunghezza focale dell'obiettivo in funzione del percorso ottimale ed al valore della ground resolution o GSD (Ground Sample Distance). La sovrapposizione tra fotogrammi, overlap, è stata impostata al il 70\% e la sovrapposizione tra le strisciate, sidelap, è stata impostata all'80\%. L'altezza contenuta delle emergenze archeologiche e la mancanza di ostacoli ha permesso un volo di prossimità che ha garantito una GSD di $\mid \mathrm{cm} /$ pixel. | fotogrammi sono stati acquisiti effettuando 6 voli, acquisendo blocchi fotogrammetrici di fotogrammi nadirali e a 45 gradi che hanno mappato completamente il sito archeologico. II software utilizzato è stato Agisoft Metashape che utilizza per la modellazione fotogrammetrica algoritmi di SfM (Structure from Motion). Le operazioni a tavolino sono state suddivise in acquisizione dei dataset di immagini; suddivisione in chunk; allineamento delle immagini, costruzione della nuvola sparsa, la costruzione della nuvola densa, meshing per ottenere un modello B-Rep (Boundary Representation), la costruzione del modello texturizzato ed infine proiezione su ortofotopiano per ottenere pianta, prospetti e sezioni. (R.C.). 


\section{II metodo range-based modeling per il rilievo integrato}

Nel caso proposto con il presente contributo, la scelta operativa perseguita ha avuto come principale obiettivo l'acquisizione dei dati metrico-dimensionali inerenti le Terme del Foro di Cuma; fine ultimo delle operazioni è stata dunque la restituzione di un rilievo tridimensionale ad alta definizione del sito che, attingendo a differenti tecniche di rilievo indiretto, offrisse una rappresentazione restitutiva integrata, cioè di analisi e di misurazioni assieme, di rilievo e di rappresentazione, idonea a comprendere e documentare il manufatto archeologico nella sua completezza.

A tal fine, la scelta metodologica applicativa ha previsto l'uso integrato dei sistema TLS (Terrestrial Laser Scanner) e SAPR (Sistemi Aeromobili a Pilotaggio Remoto), con l'obiettivo di definire e dunque disporre di un modello tridimensionale del manufatto, attraverso il quale esplorare la morfologia del sito, le connessioni e le relazioni tra le parti, nonché uno strumento che consenta di elaborare e redigere rappresentazioni che arricchiscano l'apparato documentario ad oggi a disposizione dell'impianto archeologico.

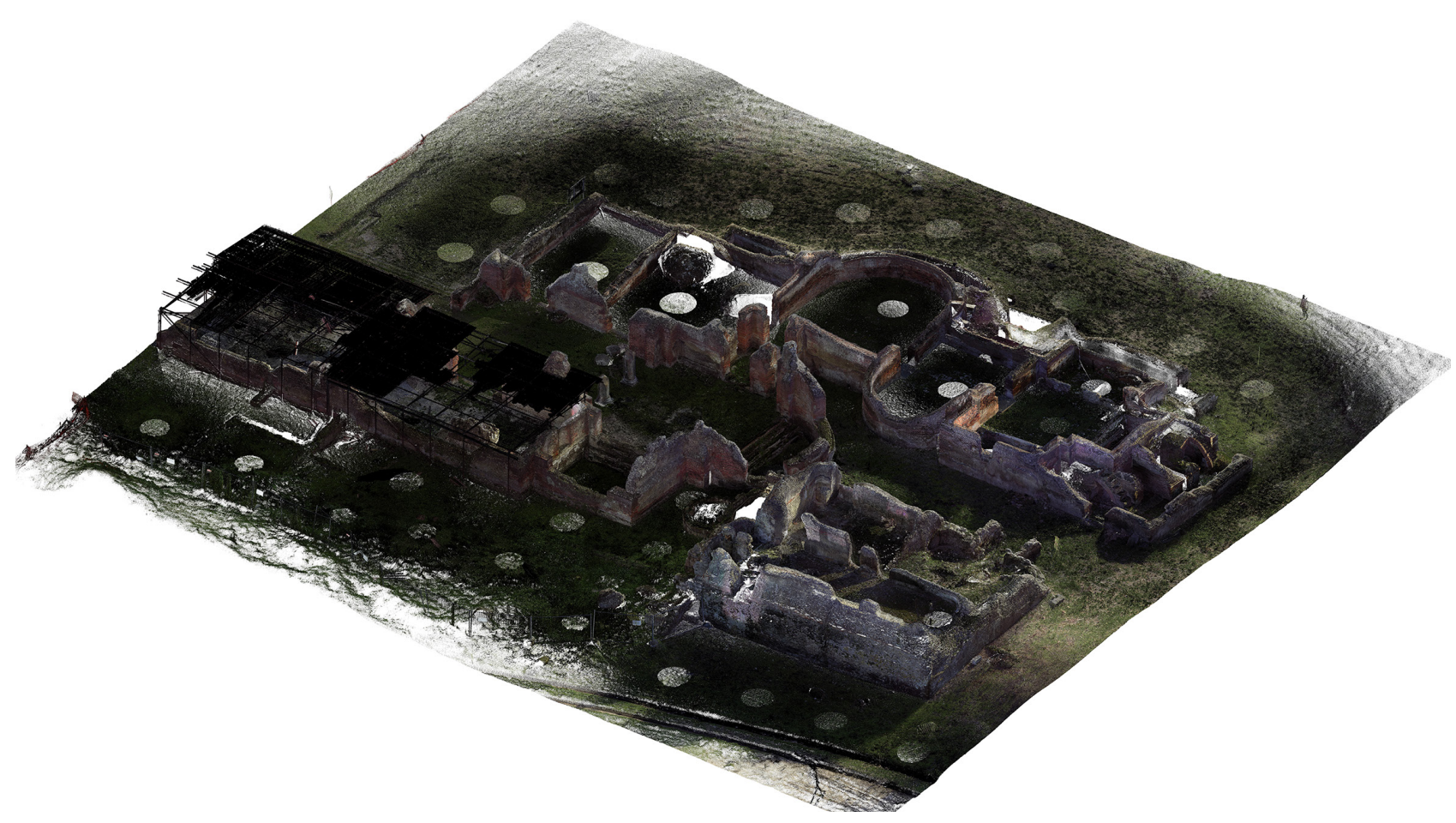

Fig. 8. Terme del Foro. Proiezione assonometrica da nuvola di punti TLS (Terrestrial Laser Scanner).
La fase di acquisizione e le successive fasi di processamento ed elaborazione dei dati sono state ponderate prendendo in considerazione sia le caratteristiche di ciascuna tecnica impiegata, sia le capacità qualitative degli strumenti adoperati (ad esempio precisione, accuratezza e formato dei dati in output), questo ai fini di una mutua integrazione dei dati rilevati.

II rilevamento in situ è stato condotto adoperando, per i rilievi con sistema TLS, lo strumento CAM2 Laser Scanner Faro Focus 3D X330, con fotocamera digitale integrata dotata di asse ottico coassiale al raggio di misura del laser e con tecnologia laser scanner a variazione di fase o Phase Shift.

Nel caso specifico, l'acquisizione dei dati, contestualmente alla registrazione delle informazioni che esprimono la posizione nello spazio (coordinate $X, Y$ e Z) di ciascun punto individuale, ha permesso di rilevare mediante la fotocamera integrata di cui è dotato lo strumento un corrispondente valore cromatico (componenti RGB) - ancora una volta per ciascun punto 
individuale - ottenendo e garantendo così una completezza di informazioni, misurando e registrando in forma digitale tridimensionale accurati dati metrici e cromatici, nonché materici al fine di documentare lo stato di conservazione del sito.

I rilievi condotti si sono dunque svolti perseguendo una logica procedurale - in fase di acquisizione dei dati - che rispondesse quanto più alle specificità del sito e che garantisse una resa tale da poter assicurare una completa integrazione tra le diverse metodologie impiegate; per questa ragione le attività di rilievo svolte con lo strumento Laser Scanner

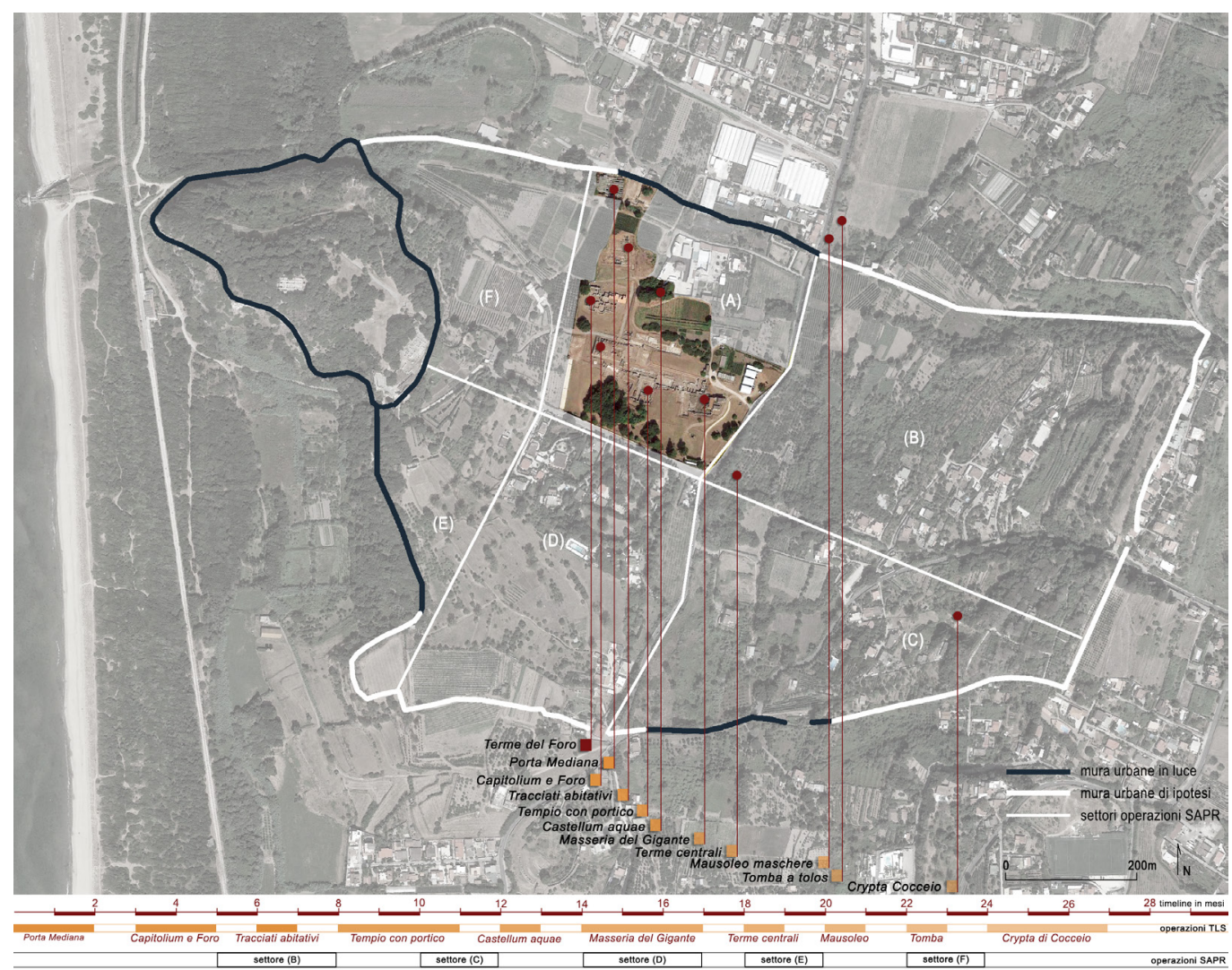

hanno previsto la pianificazione di 105 scansioni, ciascuna della durata di circa 6 minuti, aventi dimensioni in pixel di 10240×4267 e dimensioni in MPts (Million of Points) di 43,7 con qualità $3 x$; inoltre, si è impostata una risoluzione dello scanner tale che su un piano posto a 10 metri dall'emettitore due punti battuti avessero una distanza di 6,I $36 \mathrm{~mm}$. La disposizione spaziale di ciascuna delle scansioni, pur considerando le specificità e necessità dettate dalla morfologia del sito e dal costruito esistente, è stata organizzata secondo una maglia quanto più possibile regolare, in modo da assicurare, nella successiva fase di processamento dei dati, una precisa sovrapposizione dei punti di stazione e dunque una migliore compensazione dell'errore.

Le fasi di processamento ed elaborazione dei dati raccolti, con il supporto dei software Faro Scene e Pointools e dei relativi strumenti di editing, hanno così permesso in prima istanza una sovrapposizione delle singole nuvole di punti prodotte da ognuna delle scansioni effettuate, generando così una complessiva maglia tridimensionale di punti sulla quale poter intervenire con mirate operazione di sezione e inquadramento al fine di vettorializzare il rilievo, elaborando dunque rappresentazioni bidimensionali del sito, associate alla produzione di ortofoto ad alta risoluzione.(V.M., A.V.D.). 


\section{Conclusioni}

II lavoro di ricerca condotto su alcune aree e consistenze architettoniche del Parco Archeologico di Cuma, nei Campi Flegrei, ha esplorato diversi livelli di conoscenza: dalle ricche fonti documentarie e dagli apparati iconografici, che hanno restituito la preziosità delle consistenze attuali, sino alla meticolosa doppia operazione di lettura, di acquisizione dei dati e di rappresentazione, mediante il rilievo integrato.

La metodologia combinata tra gli aspetti innovativi del metodo range-based modeling (modellazione lasergrammetrica - strumentazione ottica attiva) e del metodo image-based modeling (modellazione fotogrammetrica - tecnica basata su sensori passivi), attraverso l'utilizzo di tecniche ormai consolidate per il rilievo outdoor, hanno consentito di pervenire a modelli restituivi che in primis hanno rappresentato la morfologia urbana della città bassa e l'architettura delle Terme del Foro, ed hanno permesso di procedere ad una attenta ricognizione di tutte le caratteristiche morfometriche e colorimetriche, interrogabili anche da remoto, grazie al protocollo Tomcat di Apache e all'applicativo Webshare della Faro.

L'esito della ricerca si propone come contributo qualificato per la tutela del patrimonio archeologico e per la sua valorizzazione volto a favorire e facilitare interventi di conservazione e di restauro oltre che a fornire una permanente interrogazione dei dati e una loro completa fruizione, nell'obiettivo dichiarato di procedere con la campagna di acquisizione e restituzione dei dati di tutta l'area archeologica, e di ulteriore approfondimento anche per gli altri complessi della città bassa, il Capitolium, il Tempio con portici sul lato meridionale della piazza, la Masseria del Gigante e le Terme centrali [I].

Fig. 10. Fruizione ed interrogazione dei dati rilevati su Internet. Interfaccia della web application Faro WebShare.

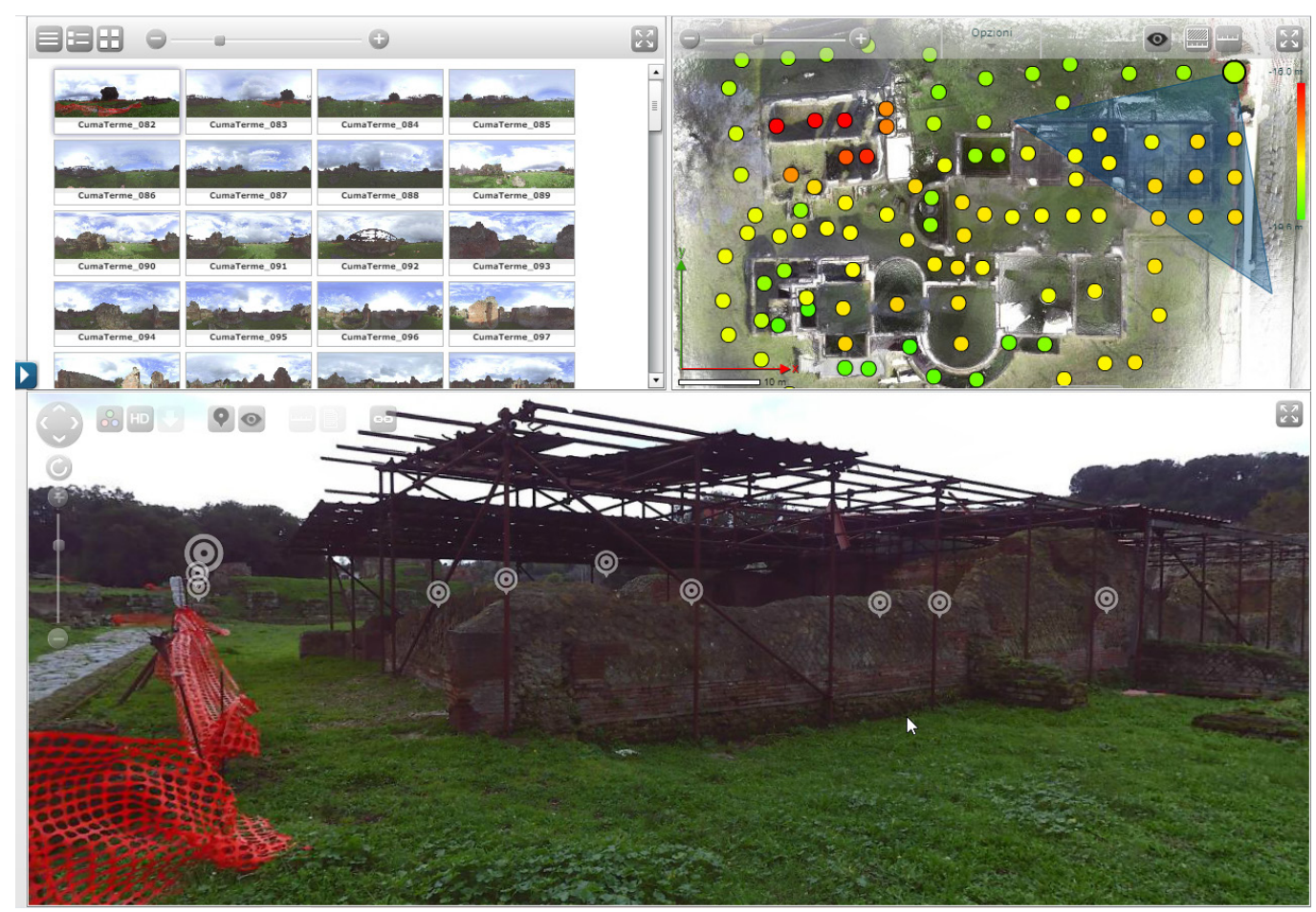

Note

[I] Le operazioni di rilievo TLS sono state condotte con la consulenza scientifica dell'archeologo Marco Giglio.I voli per le operazioni SAPR sono stati effettuati dall'arch. Marco Facchini. 


\section{Riferimenti bibliografici}

Benedetti Benedetto, Gaiani Marco, Remondino Fabio (a cura di). (20 I0). Modelli digitali 3D in archeologia. II caso di Pompei. Pisa: Edizioni della Normale.

Bertocci Stefano, Parrinello Sandro (20 I5). Digital survey and documentation of the archaeological and architectural sities. UNESCO world heritage list. Firenze: Edifir.

Brusaporci Stefano (20I5). The Representation of Architectural Heritage in the Digital Age. In Khosrow-Pour Mehdi (ed.) Encyclopedia of Information Science and Technology. Third edition. Hersey (PA): IGI Global, pp. 4I95-4205.

Caputo Paolo (1994). Cuma. Terme del Foro. Saggi di scavo. In BA, I I- I2/1994, pp. I73- 175

Caputo Paolo, Morichi Ruggero, Paone Rosario, Rispoli Paola (1996). Cuma e il suo Parco Archeologico. Un territorio e le sue testimonianze. Roma: Bardi Editore.

Centofanti Mario, Brusaporci Stefano, Lucchese Vittorio (20।4). Architectural Heritage and 3D Models. In Paolo Di Giamberardino et al. (a cura di), Computational Modeling of Object presented in Image, III: Fundamentals, Methods and Applications. Ginevra: Springer. pp. 31-49.

d'Agostino Bruno, Giglio Marco (a cura di). (20I2). Cuma Le fortificazioni 3. Lo scavo 2004 - 2006. Cava de'Tirreni: Direzione regionale per i Beni culturali e paesaggistici della Campania, vol. 2/20 I2, 363 pp.

D'Acunto Matteo, Barbato Mariangela, Gelone Marcello, Giglio Marco, lavarone Stefano, Borriello Giovanni, Napolitano Sara (20 I5). Abitato antico di Cuma (NA), campagna di scavo 20 I4. Newsletter di Archeologia CISA, 6/20 I 5, pp. I 79 - I90.

d'Agostino, Bruno, D'Andrea Andrea (a cura di). (2002). Cuma. Nuove forme di intervento per lo studio del sito antico. Napoli: Edizione Luì.

Gasparri Carlo, Greco Giovanna (a cura di). (2009). Cuma Indagini archeologiche e nuove scoperte. Napoli: Naus.

Medri Maura, Pizzo Antonio (a cura di). (2019). Le Terme Pubbliche nell'Italia Romana (II secolo a.C. - fine IV d.C.). Architettura Tecnologia Società. Seminario Internazionale di Studi. Roma 4, 5 ottobre 20 I8. Roma: Roma Tre Press.

Nielsen Inge (1990). Thermae et Balnea. The Architecture and Cultural History of Roman Public Baths. Aarhus: Aarhus University Press.

Paris Leonardo (2010). Quantità e qualità nell'utilizzo dello scanner laser 3D per il rilievo dell'architettura. In X Congreso International Espresiòn gràfica aplicada a la edificatiòn. Alicante 2-4 december 20 10. Alcovy: Editorial Marfil, vol. I, pp. $279-289$.

\section{Autori}

Riccardo Florio, Università degli Studi di Napoli Federico II, riccardo.florio@unina.it Raffaele Catuogno, Università degli Studi di Napoli Federico II, raffaele.catuogno@unina.it

Teresa Della Corte, Università degli Studi di Napoli Federico II, teresa.dellacorte@unina.it

Veronica Marino, Università degli Studi di Napoli Federico II, vero.marino@hotmail.it

Antonia Valeria Dilauro, Università degli Studi di Napoli Federico Il, dilaurovaleria@hotmail.it

Per citare questo capitolo: Florio Riccardo, Catuogno Raffaele, Della Corte Teresa, Marino Veronica, Dilauro Valeria Antonia (2020). Architettura archeologia per il rilievo integrato, il caso esemplare di Cuma: le Terme del Foro/Archeology architecture for the integrated survey, the exemplary sase of Cuma: the Foro Thermal Baths. In Arena A., Arena M., Brandolino R.G., Colistra D., Ginex G., Mediati D., Nucifora S., Raffa P. (a cura di). Connettere. Un disegno per annodare e tessere. Atti del $42^{\circ}$ Convegno Internazionale dei Docenti delle Discipline della Rappresentazionel Connecting. Drawing for weaving relationships. Proceedings of the 42th International Conference of Representation Disciplines Teachers. Milano: FrancoAngeli, pp. $2182-2203$ 


\title{
Archeology Architecture for the Integrated Survey, the Exemplary Case of Cuma: the Foro Thermal Baths
}

\author{
Riccardo Florio \\ Raffaele Catuogno \\ Teresa Della Corte \\ Veronica Marino \\ Antonia Valeria Dilauro
}

\section{Abstract}

This contribution wants to illustrate the explorative and operational phases of data acquisition of an archaeological site of significant importance, the Archaeological Park of Cuma, with an in-depth information on the Terms of the Foro. Here will be described the different study phases that through a reasoned mapping of the pre-existences are allowing the working group to perform a strict recognition and acquisition of the entire city within the walls, the acropolis and the low city, that will allow the documentation and transfer of data on the network to allow its wide and controlled use, even from the scientific point of view.

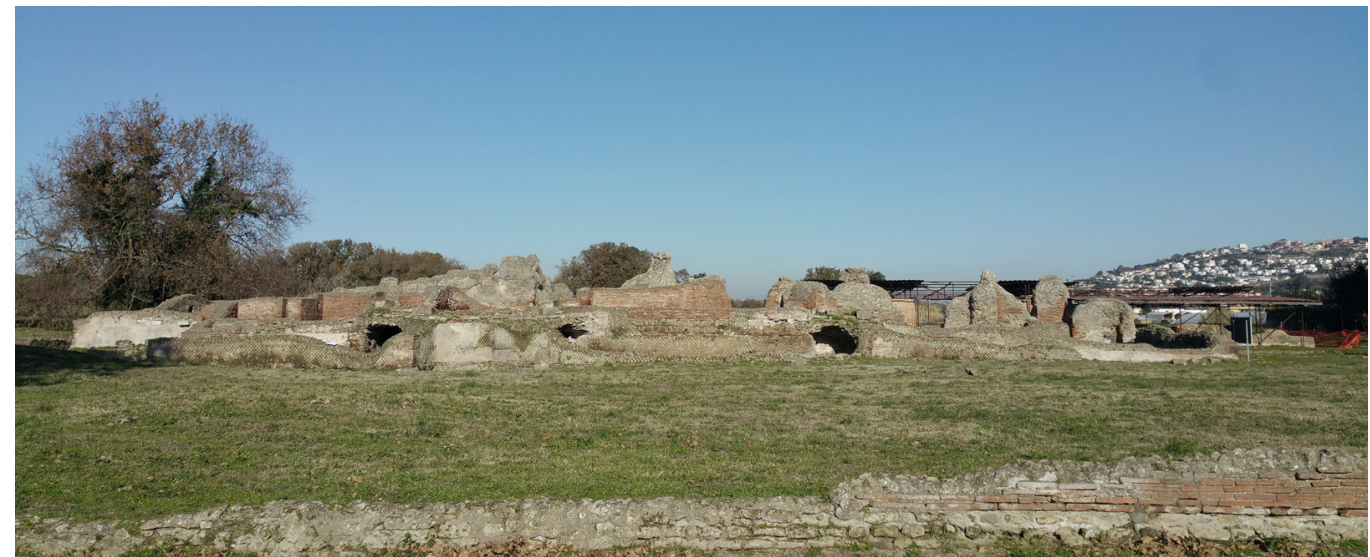




\section{Integrated survey methodologies for the knowledge of Cuma's archaeological site}

The research work that we present here concerns the study and comparative reading, through a careful integrated survey, of the architectures and archaeological remains located within the Archaeological Park of Cuma, extended over a large area of the northern limit of the Phlegrean Fields.

The places, originally, were completely different from the current structure, especially for the significant variations of the coast line compared to the ancient one, the hill on which the Cuma's site would have settled was originally lapped on three sides by the sea, accessible only from the south and in the north the marshy territory provided it further natural defenses.

The polis of Cuma was founded by the Greeks, coming from nearby Pithekoussai (Ischia), in 730 B.C. , by establishing the Acropolis and the sanctuaries on the hill, and at the base of it, in a flat and wide area, the town was built. The so-called low city was delimited by an irregular quadrilateral of urban walls and extended for an area of about I I 0 ha. From the evidence that emerged from recent studies, the layout of the city was not of the hippodameo type, but some axes more or less parallel to the coast were identified which supported the morphological structure of the soil and divided the city into sectors; these intersected with other smaller orthogonal axes. The sporadic explorations conducted in the eighteenth and twentieth centuries revealed evidence of buildings from the Samnite and Roman period, especially in the area of the Forum with its tuff portico: the Capitolium, the Temple with arcades on the southern side of the square, the masseria del Gigante, the Central Baths and the Baths of the Forum.

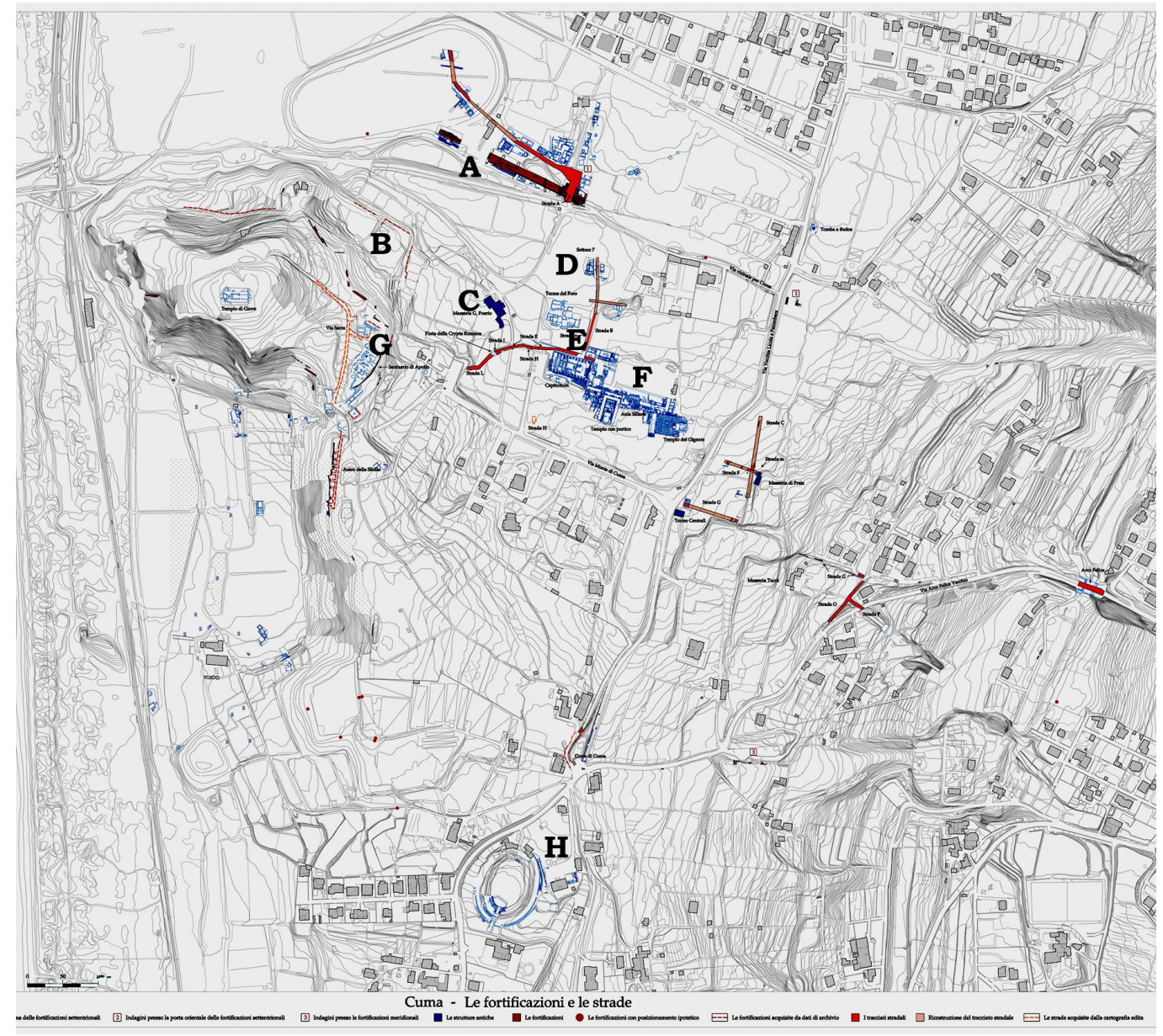


The study focused, in this phase, on the lower city with the main objective of developing two different investigation phases: one with a broad spectrum that can return all the consistencies and is able to define, with scientific measurements, the perimeters of the current excavations and give useful information for future operations; the other, absolutely related to the first, of in-depth reading of one of the most relevant complexes: the Foro's thermae.

The integrated surveying operations aimed the creation of a reusable and implementable framework based on the experimentation of the various possibilities, linked, for example, to the size, type and/or difficulty of data acquisition. No-contact techniques based on both image-based and laser-based technology were used, taking advantage of photography and laser scanning in an integrated way. In particular, the TLS (Terrestrial Laser Scanner) system was adopted for the high resolution acquisition of the morphometric consistencies of the architectures and findings, and the UAV (Unmanned Aerial Vehicle) was used to acquire images and videos that document the cultural heritage as a whole; through scheduled flight operations, images were acquired for photogrammetric modeling, allowing the construction of a measurable digital model of the archaeological site.

The operations were carried out according to an integrated methodology that, synergistically making use of the accuracy of the innovative instruments and the peculiar comparative attitude of the layering and 3D representation methods and of digital photomodeling, wants to be grafted successfully into the traditional cognitive process.

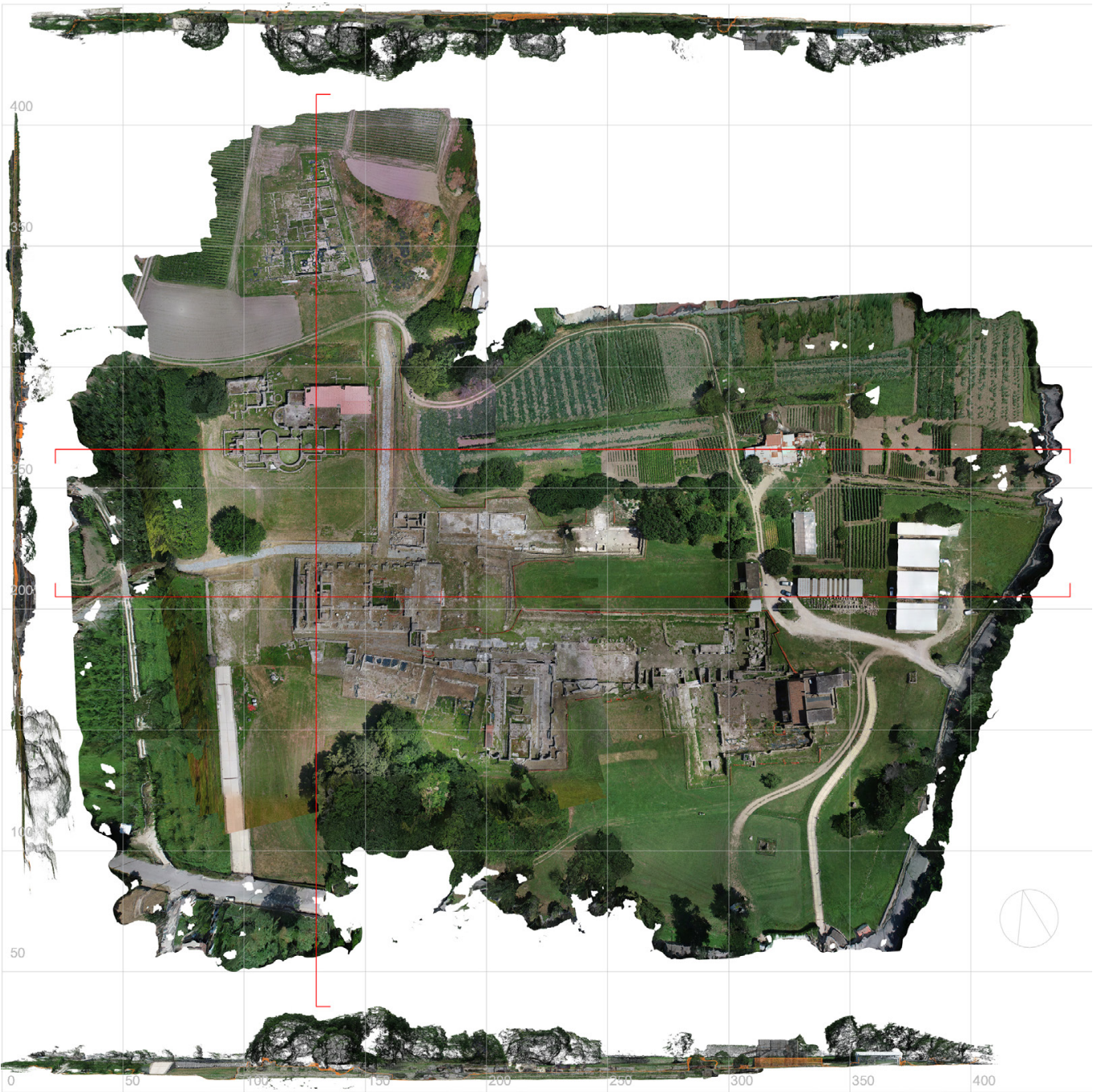


On the basis of the numerous data returned, we wanted to establish a re-decoding process that shifts the reading from the figurative transpositions of the eighteenth and nineteenthcentury manuals, in its cognitive, taxonomic and reconstructive need, to the representative form of the present.

The analytical-mathematical restitution of the numerical processes, founding the circular recourse of the assumption of information, has made possible to find the material and architectural characteristics of the ancient vestiges and their geometric roots, but has also provoked a revelation that has proclaimed the specifics urban and architectural peculiarities. (R.F.)

\section{Historical-architectural analysis and identification of construction phases}

The study of the ancient plant was aimed at deepening its historical-architectural analysis through the synergistic integration between the most advanced detection technologies. By inserting itself into the dynamic cognitive process of complex archaeological sites that require progressive interpretative updates, the operations carried out have made it possible to identify, and register in the representation, the peculiarities of the complex, adding to the archaeological studies and previous documentations accurate graphic and infographic documentation, for project the necessary interdisciplinary diligence towards a correct site protection and enhancement policy.

The immediate and punctual intelligibility of the surviving architectural-archaeological textures supported the fundamental, and necessary, hermeneutic role inherent in the reconstruction of the life phases of the thermal complex: not only were the relationships between the original rooms condensed in the remains highlighted, but also, effectively, the variations and anomalies present between the different wall textures, enhancing the most latent traces, such as the material and chromatic ones, able to reveal and therefore scientifically validate the layered structures relating to the various epochs.

Built on a pre-existing residential settlement, the original plant of the Forum thermal baths is currently traced back to the end of the Ist century, probably in the Hadrian era, in reference to an intense phase of construction activity that followed the construction in 95 of the via Domitiana. The most decisive factors for the reliability of this dating are, however, attributable to the use of masonry and materials of that era in the Phlegraean territorial context, but above all the typological correspondence of the complex plan with the halfaxial ring type, very widespread in Roman Italy of the period.

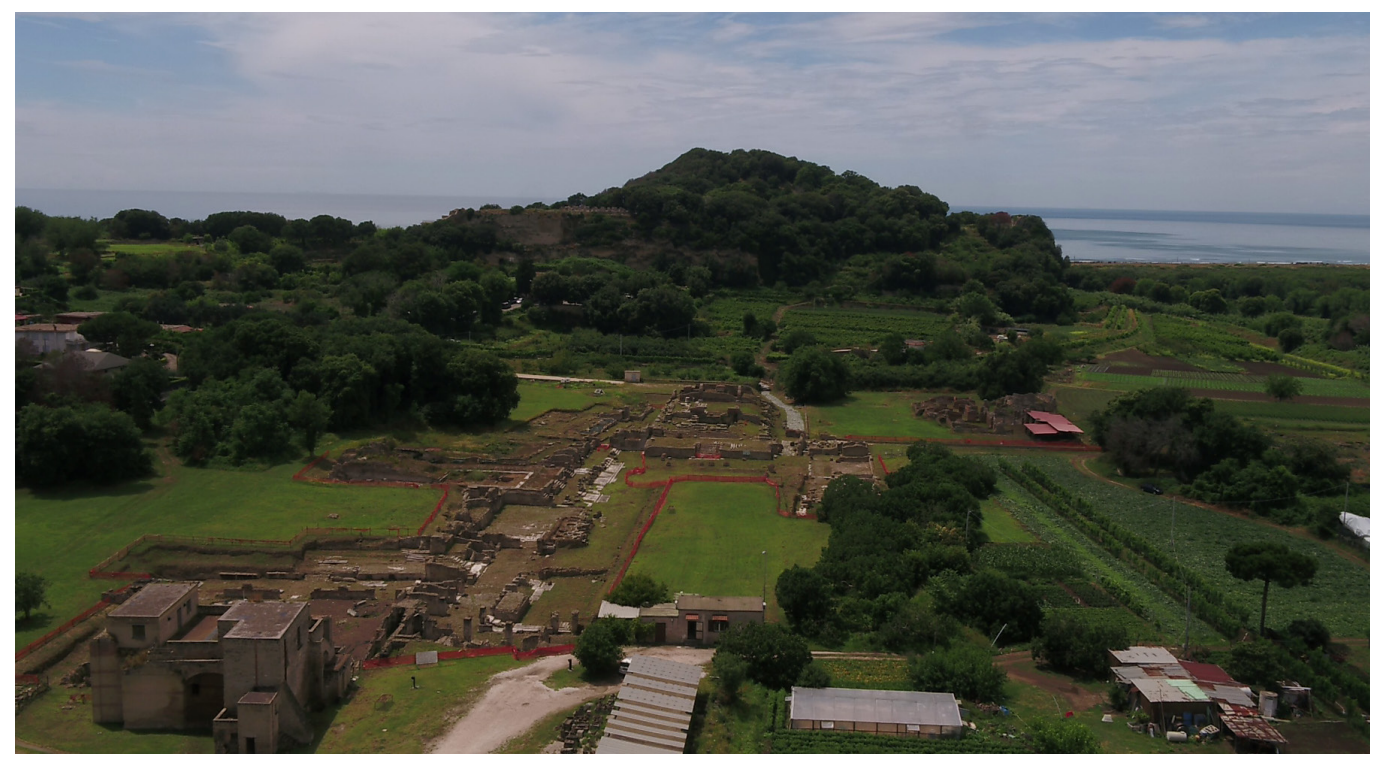


The articulation of the rooms in situ is configured in a semi-symmetrical way, favoring the scenographic axiality dominated by two large columns in Caristo marble and stretched between the entrance vestibule and the semicircular tub of the frigidarium, organizing on a parallel secondary axis the mixtilinear concatenation of warm spaces culminating in the calidarium. The sequence of these finds in the remains the peculiarity of the progressive increase in temperature towards the prefurnia. The examination of the wall partitions revealed that the rectangular room north-east of the vestibule and the room placed before the thermal path and near the gymnasium, used for massages, were contextual to the original layout. The only temporally non-contextual space is the square room next to the entrance, added in a later period as shown by the use of different materials and the detachment of the walls adjacent to those of origin. The integration of data made it possible to formulate the hypothesis of a long life and functionality testified by numerous conservation and consolidation interventions of the structures. Other traces, changing the usability of some spaces, give consistency to the hypothesis of a subsequent function of the complex, non-permanent and anticipatory of abandonment at the end of the 5th century; a more lasting reuse seems to have affected the cistern structures. (T.D.C.)

Fig. 4. Schematization of the characteristics of the original plant and of the construction phases of the site of the thermal baths of the Foro [Guardascione 2019]; indication of the sequence of hot, cold, hallway and service spaces.
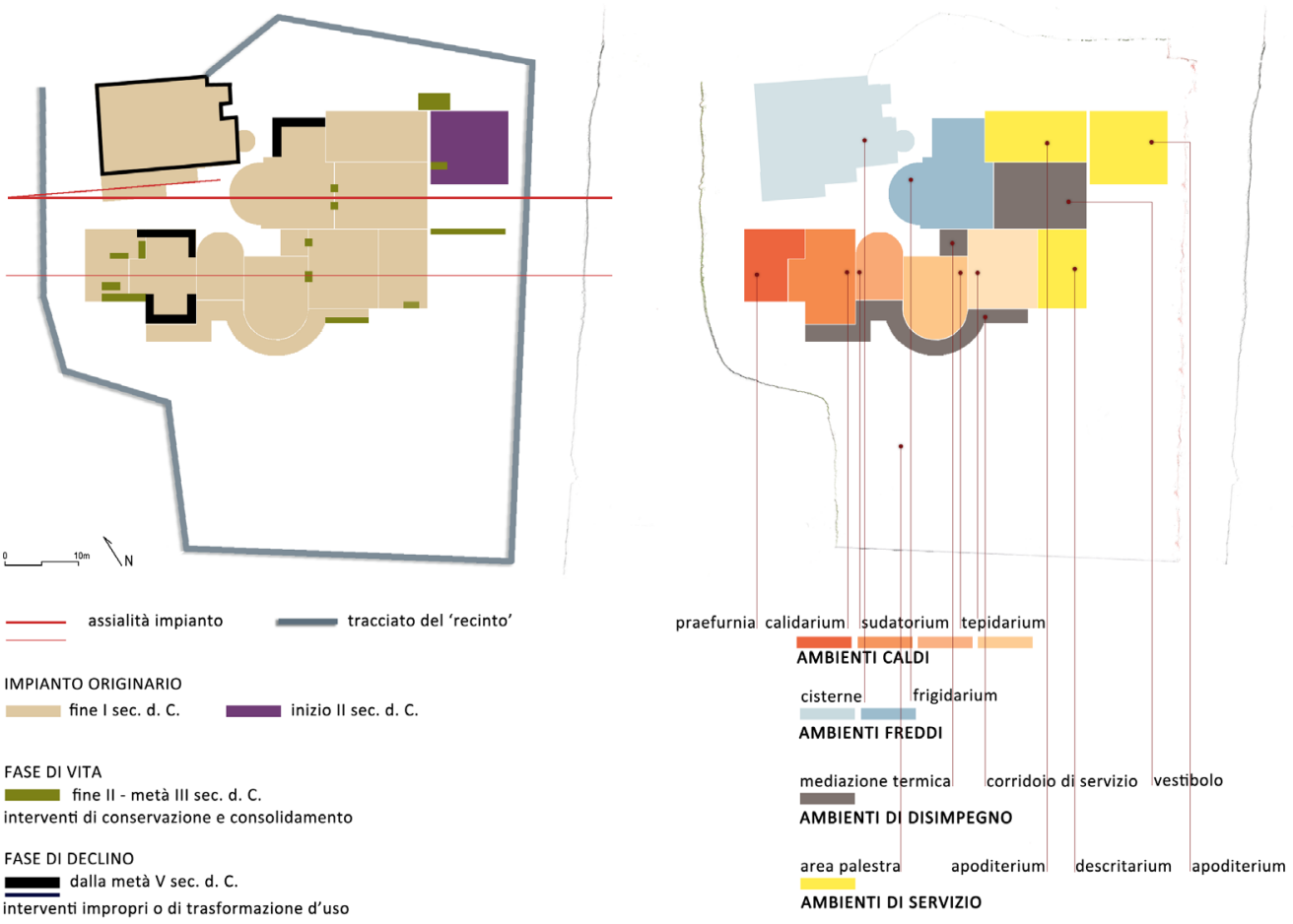

The image-based modelling method for the integrated survey

For Cuma's Archaeological Park, in particular for the lower town, two important campaigns were carried out in June 2018 and June 2019, returning two areas close to the Forum Baths, appropriately geo-referenced through GCP (ground control points) distributed along the perimeter and inside the detected area and materialized through RAD, for an area of I 00,000 square meters. The work of acquiring images, processing and returning the data lasted two months. For the methodology choice, after two preliminary inspections for planning the operations needed, was decided that the most suitable one was the photogrammetric modeling for a framing of the area with the return of a first model, while for the survey of archaeological emergencies an instrumental survey with laser scanner was chosen. 


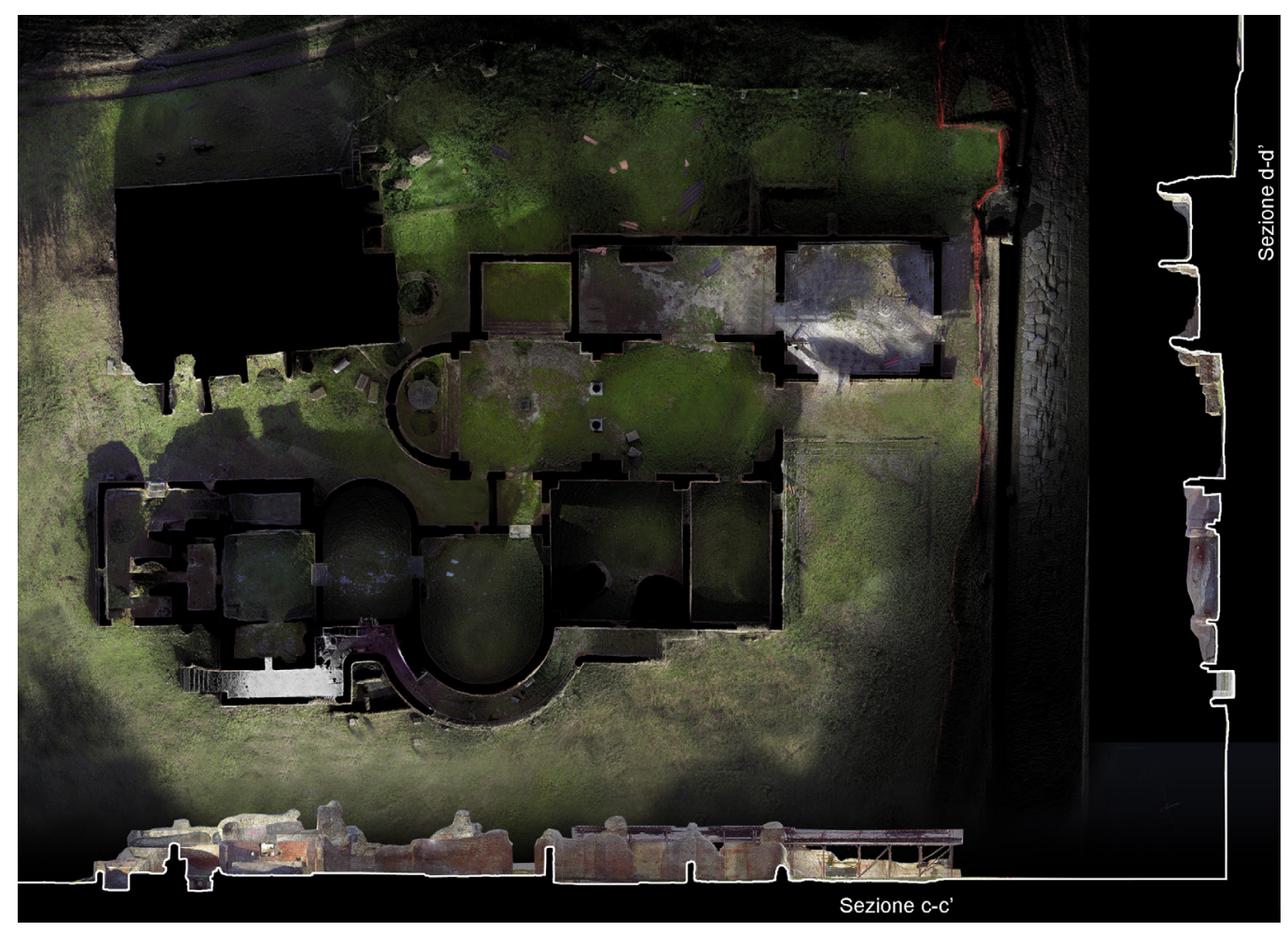

Figg. 5, 6. Foro's thermae Orthoprojection and point cloud sections TLS (Terrestrial Laser Scanner).

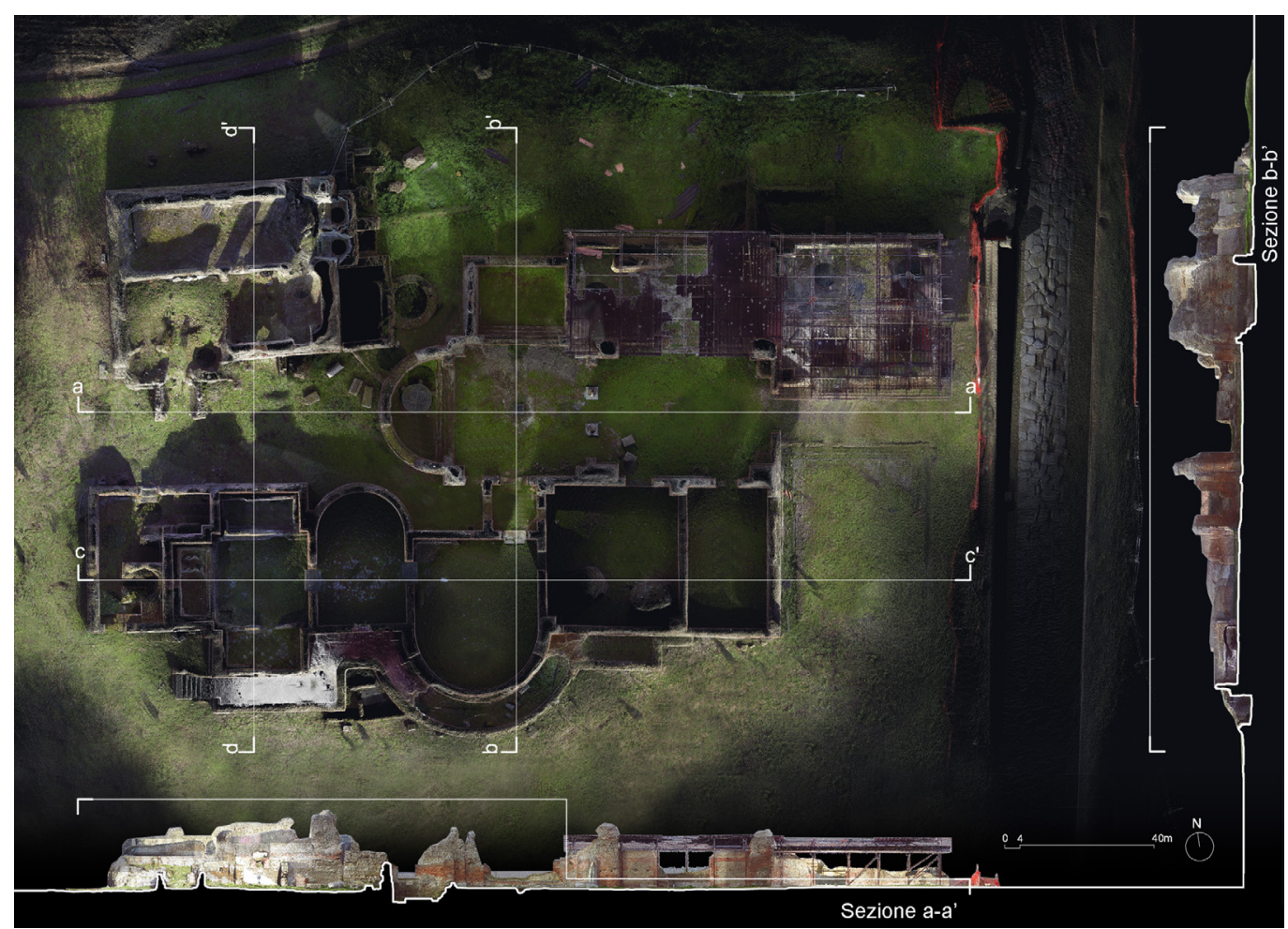


Fig. 7. Architectural analysis of hot spaces (praefurnia, calidarium, tepidarium) conducted tepidarium) conduct by processing and coln scanner technology. The overall configurations of hypocaustum and concameratio are deduced from the remains accessible on site.
Other flights of equal extension will be made to acquire the entire area with 6 missions, using topographic points to join the different surveys, while, as for the Foro's thermae, we will proceed to further investigations with instrumental survey with laser scanner.

In fact, this technique allowed the acquisition of morpho-metric data of the archaeological site in question, restoring the consistency of the emergencies present in the area.

The process was aimed for the creation of a three-dimensional model for the reconstruction of the state of fact as investigation tool for the creation of orthophotopians of the site.

Then we proceeded with the acquisition through UAV (Unmanned Aerial Vehicle) of aerial images both nadiral and at different angles to be used in the photogrammetric modeling software. A preliminary setting project was required based on the mapping of the area with Mission Planner, a software for the creation of the flight plan by setting the altitude of the aircraft, focal length of the objective according to the optimal route and

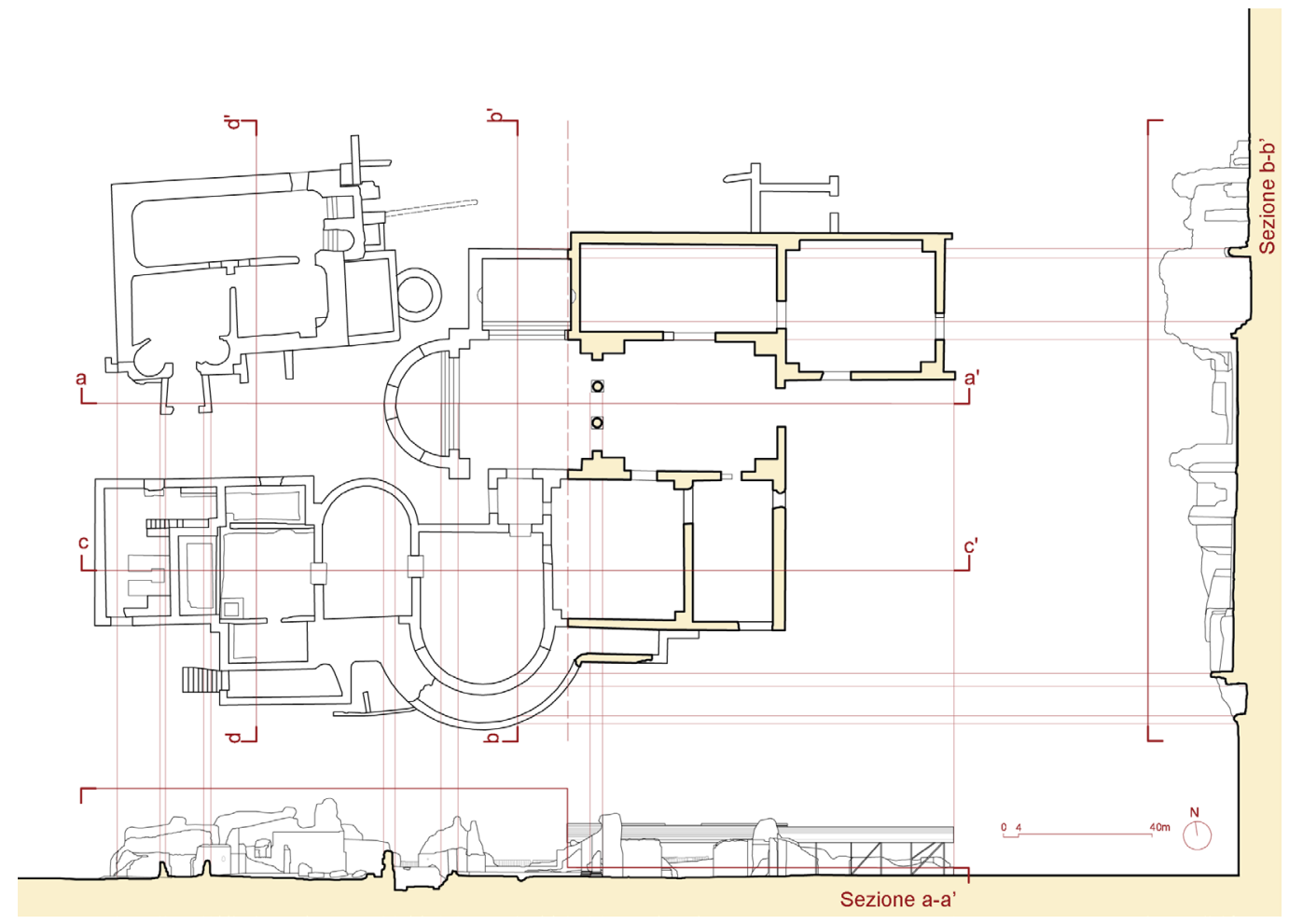

value ground resolution or GSD (Ground Sample Distance). The overlap between frames has been set to $70 \%$ and the sidelap overlap has been set to $80 \%$. The limited height of the archaeological emergencies and the lack of obstacles allowed a proximity flight which guaranteed a GSD of I cm/pixel. The frames were acquired by making 6 flights, acquiring photogrammetric blocks of nadiral frames and at 45 degrees which completely mapped the archaeological site.

The software used was Agisoft Metashape which uses SfM (Structure from Motion) algorithms for photogrammetric modeling. The desk operations were divided into acquisition of image datasets; chunk subdivision; alignment of the images, construction of the scattered cloud, construction of the dense cloud, meshing to obtain a B-Rep (boundary representation) model, construction of the textured model and finally projection on the orthophotoplan to obtain plan, elevations and sections. (R.C.) 


\section{The range-based modelling method for the integrated survey}

In the case proposed with this contribution, the operational choice pursued had as main objective the acquisition of metric-dimensional data concerning the Thermae of the Cuma's Forum; therefore the final aim of the operations was the restitution of a three-dimensional high-definition survey of the site that, drawing on different techniques of indirect survey, would offer an integrated restitutive representation, analysis and measurements together, survey and representation, suitable to understand and document the archaeological artifact in its completeness.

To this end, the methodological-applicative choice has provided for the integrated use of the TLS (Terrestrial Laser Scanner) and UAV (Unmanned Aerial Vehicle), with the aim of defining and having a three-dimensional model of the artefact, through which to explore the morphology of the site, the connections and relations between the parts, therefore a tool that allows to elaborate and draw up representations that enrich the documentary apparatus currently available to the archaeological site.

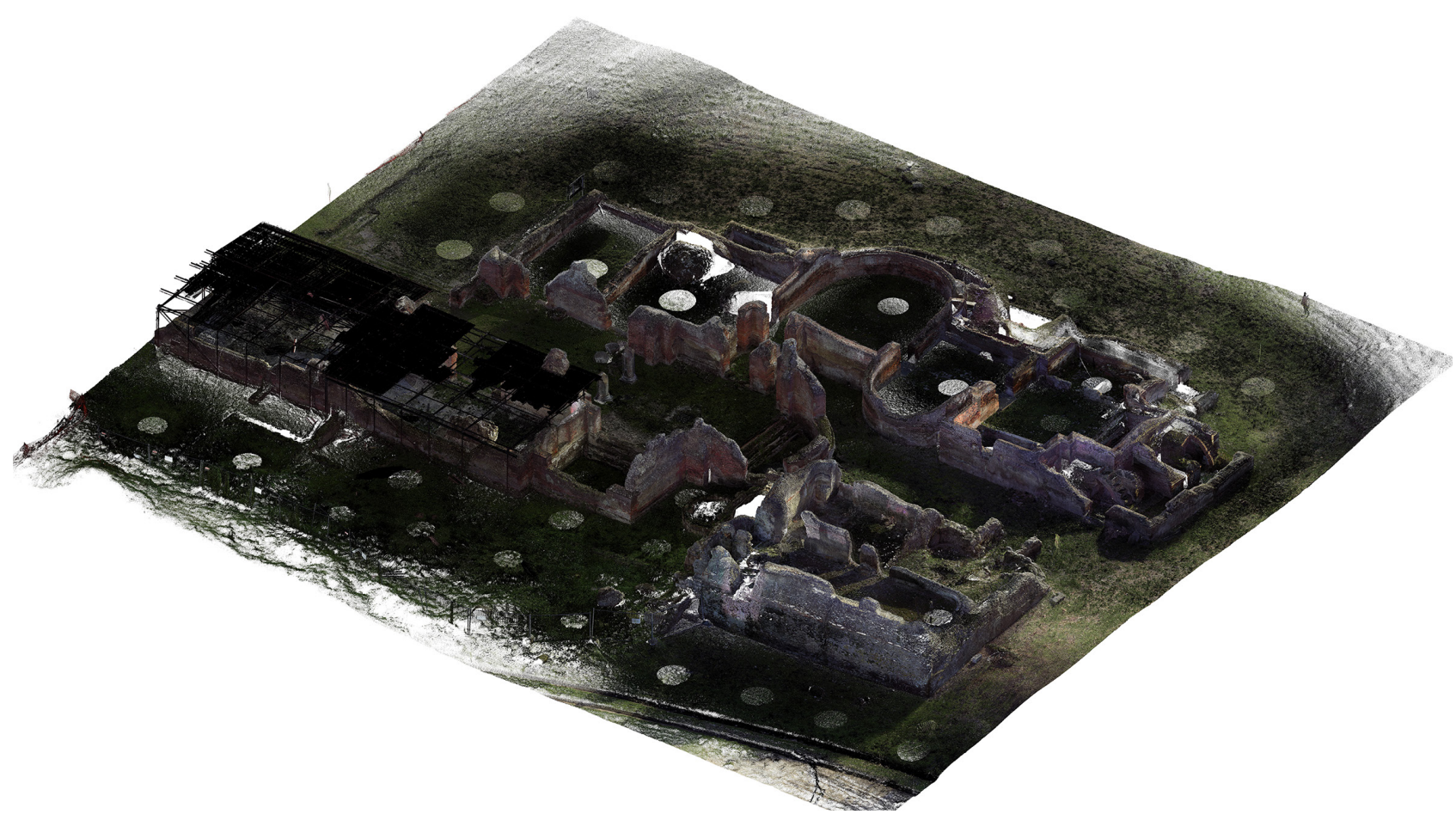

Fig. 8. Foro's thermae. Axonometric projection from point cloud TLS (Terrestrial Laser Scanner).
The acquisition phase and the subsequent phases of data processing and elaboration have been weighted taking into account the characteristics of each technique applied and the qualitative capabilities of the instruments used (for example precision, accuracy and format of the output data), this for the purpose of mutual integration of the data collected.

for the survey with TLS system conducted in situ was used the CAM2 Laser Scanner Faro Focus 3D X330, with integrated digital camera equipped with optical axis coaxial to the laser measurement range and with phase shift laser scanner technology.

In this specific case, the acquisition of data, together with the recording of information expressing the position in space of each individual point ( $X, Y$ and $Z$ coordinates), made it possible to census, using the integrated camera with which the instrument is equipped, a corresponding chromatic value (RGB components) - once again for each individual point - obtaining and guaranteeing a completeness of information, measuring and recording 
accurate metric and chromatic data in digital three-dimensional format, but also material information in order to document the state of conservation of the site.

During the data acquisition phase, the surveys were carried out in accordance with a procedural logic that responded to the specific characteristics of the site and that guaranteed a yield that ensured complete integration between the different methodologies used; for this reason, the survey activities carried out with the Laser Scanner tool have planned I05 scans, each lasting about 6 minutes, with pixel dimensions of 10240×4267 and MPts

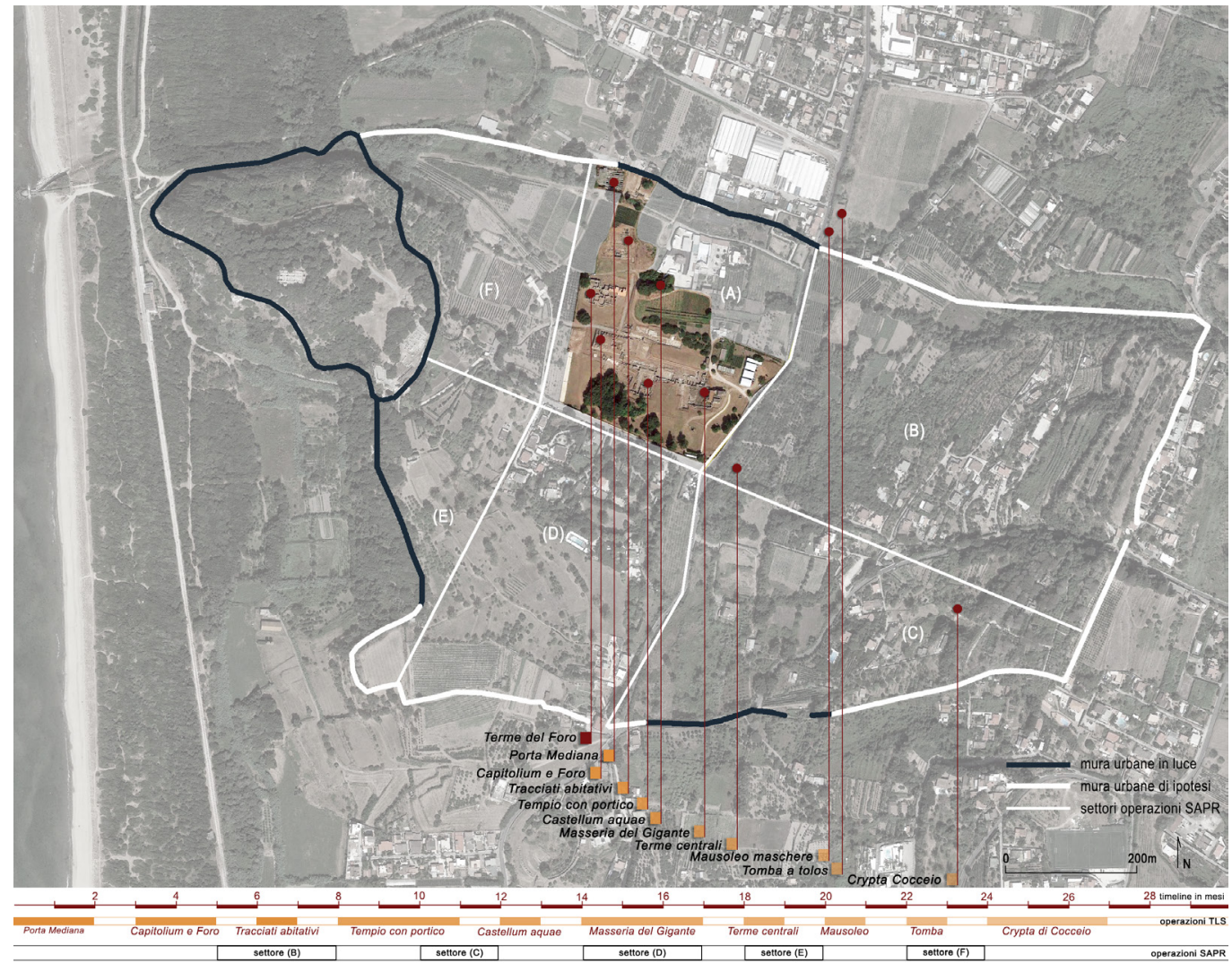

dimensions (millions of points) of 43.7 with $3 \times$ quality; moreover, a resolution of the scanner has been set such that on a plane placed at 10 meters from the emitter two beaten points had a distance of $6.136 \mathrm{~mm}$. While taking into account the specificities and needs dictated by the morphology of the site and the existing structure, the spatial arrangement of each scan has been organised according to a grid that is as regular as possible, in order to ensure, in the subsequent data processing phase, precise overlapping of the station points and thus better compensation for error.

The phases of processing and elaboration of the collected data, with the support of Faro Scene and Pointools software and related editing tools, in the first instance allowed an overlapping of the single point clouds produced by the scans made, generating an overall three-dimensional grid of points on which to intervene with targeted sectioning and framing operations in order to vectorize the survey, elaborating two-dimensional representations of the site, associated with the production of high resolution orthophotos.(V.M.,A.V.D.). 


\section{Conclusions}

The research work carried out on some areas and architectural textures of the Archaeological Park of Cuma, in the Phlegraean Fields, has explored different levels of knowledge: from the rich documentary sources and iconographic systems, that have returned the preciousness of the current textures, up to the meticulous double reading, data acquisition and representation, through the integrated survey.

The combined methodology between the innovative aspects of the range-based modeling method (lasergrammetric modeling - active optical instrumentation) and the image-based modeling method (photogrammetric modeling - technique based on passive sensors), through the use of well-established techniques for surveying outdoor, allowed us to arrive at restorative models that primarily represented the urban morphology of the lower city and the architecture of the Foro's thermae, and allowed us to proceed with a careful recognition of all the morphometric and colorimetric characteristics, that can also be interrogated remotely , thanks to Apache's Tomcat protocol and Faro's Webshare application.

The outcome of the research proposes itself as a qualified contribution for the protection of the archaeological heritage and for its enhancement aimed to promoting and facilitating conservation and restoration interventions as well as providing a permanent query of the data and their complete use, in the stated objective to proceed with the data acquisition and return campaign for the entire archaeological area, and as further study also for the other complexes of the lower city, the Capitolium, the Temple with arcades on the southern side of the square, the masseria del Gigante and the Central thermae [I].

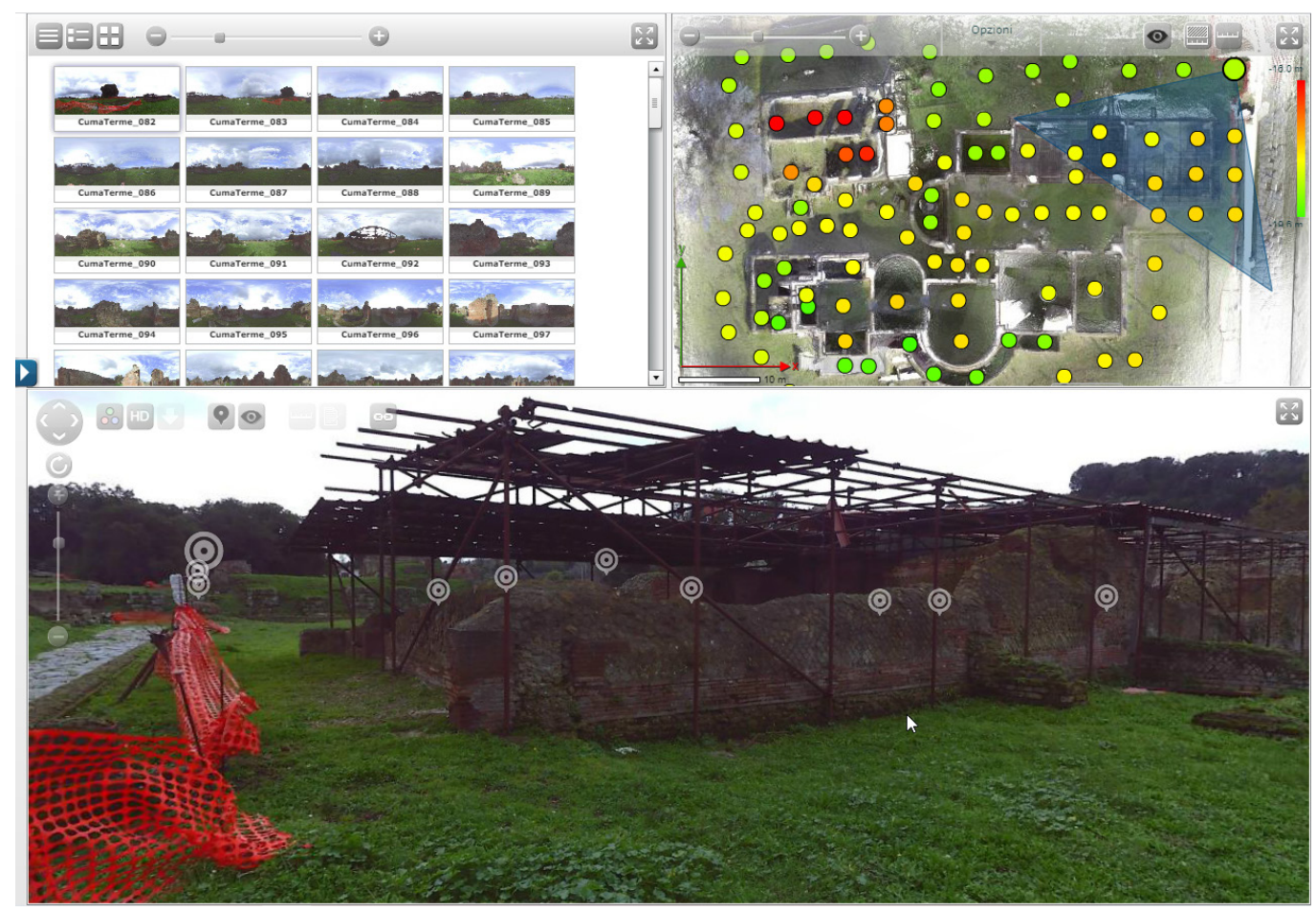

Notes

[I]The TLS survey operations were carried out with the scientific advice of the archaeologist Marco Giglio. The flights for the SAPR operations were carried out by the architect Marco Facchini. 


\title{
References
}

Benedetti Benedetto, Gaiani Marco, Remondino Fabio (a cura di). (20 I0). Modelli digitali 3D in archeologia. II caso di Pompei. Pisa: Edizioni della Normale.

Bertocci Stefano, Parrinello Sandro (20 I5). Digital survey and documentation of the archaeological and architectural sities. UNESCO world heritage list. Firenze: Edifir.

Brusaporci Stefano (20I5). The Representation of Architectural Heritage in the Digital Age. In Khosrow-Pour Mehdi (ed.). Encyclopedia of Information Science and Technology. Third edition. Hersey (PA): IGI Global, pp. 4I95-4205.

Caputo Paolo (1994). Cuma. Terme del Foro. Saggi di scavo. In BA, I I I 2/I994, pp. I73- 175

Caputo Paolo, Morichi Ruggero, Paone Rosario, Rispoli Paola (1996). Cuma e il suo Parco Archeologico. Un territorio e le sue testimonianze. Roma: Bardi Editore.

Centofanti Mario, Brusaporci Stefano, Lucchese Vittorio (20।4). Architectural Heritage and 3D Models. In Paolo Di Giamberardino et al. (a cura di), Computational Modeling of Object presented in Image, III: Fundamentals, Methods and Applications. Ginevra: Springer. pp. 31-49.

d'Agostino Bruno, Giglio Marco (a cura di). (20I2). Cuma Le fortificazioni 3. Lo scavo 2004 - 2006. Cava de'Tirreni: Direzione regionale per i Beni culturali e paesaggistici della Campania, vol. 2/20 I2, 363 pp.

D'Acunto Matteo, Barbato Mariangela, Gelone Marcello, Giglio Marco, lavarone Stefano, Borriello Giovanni, Napolitano Sara (20 I5). Abitato antico di Cuma (NA), campagna di scavo 20 I4. Newsletter di Archeologia CISA, 6/20 I 5, pp. I 79 - I90.

d'Agostino, Bruno, D'Andrea Andrea (a cura di). (2002). Cuma. Nuove forme di intervento per lo studio del sito antico. Napoli: Edizione Luì.

Gasparri Carlo, Greco Giovanna (a cura di). (2009). Cuma Indagini archeologiche e nuove scoperte. Napoli: Naus.

Medri Maura, Pizzo Antonio (a cura di). (2019). Le Terme Pubbliche nell'Italia Romana (II secolo a.C. - fine IV d.C.). Architettura Tecnologia Società. Seminario Internazionale di Studi. Roma 4, 5 ottobre 20 I8. Roma: Roma Tre Press.

Nielsen Inge (1990). Thermae et Balnea. The Architecture and Cultural History of Roman Public Baths. Aarhus: Aarhus University Press.

Paris Leonardo (20I0). Quantità e qualità nell'utilizzo dello scanner laser 3D per il rilievo dell'architettura. In X Congreso International Espresiòn gràfica aplicada a la edificatiòn. Alicante 2-4 december 20 I0. Alcovy: Editorial Marfil, vol. I, pp. $279-289$.

\author{
Authors \\ Riccardo Florio, University of Naples Federico II, riccardo.florio@unina.it \\ Raffaele Catuogno, University of Naples Federico II, raffaele.catuogno@unina.it \\ Teresa Della Corte, University of Naples Federico II, teresa.dellacorte@unina.it \\ Veronica Marino, University of Naples Federico II, vero.marino@hotmail.it \\ Antonia Valeria Dilauro, University of Naples Federico II, dilaurovaleria@hotmail.it
}

To cite this chapter. Florio Riccardo, Catuogno Raffaele, Della Corte Teresa, Marino Veronica, Dilauro Valeria Antonia (2020). Architettura archeologia per il rilievo integrato, il caso esemplare di Cuma: le Terme del Foro/Archeology architecture for the integrated survey, the exemplary sase of Cuma: the Foro Thermal Baths. In Arena A., Arena M., Brandolino R.G., Colistra D., Ginex G., Mediati D., Nucifora S., Raffa P. (a cura di). Connettere. Un disegno per annodare e tessere. Atti del $42^{\circ}$ Convegno Internazionale dei Docenti delle Discipline della Rappresentazione/Connecting Drawing for weaving relationships. Proceedings of the 42th International Conference of Representation Disciplines Teachers. Milano: FrancoAngeli, pp. $2182-2203$ 